\title{
Time trends in nutrient intake and dietary patterns among five birth cohorts of 70- year-olds examined 1971-2016: results from the Gothenburg H70 birth cohort studies, Sweden
}

\author{
Jessica Samuelsson ${ }^{1 *}$ (D), Elisabet Rothenberg ${ }^{2}$, Lauren Lissner ${ }^{3}$, Gabriele Eiben $^{4}$, Anna Zettergren ${ }^{1}$ and
} Ingmar Skoog'

\begin{abstract}
Background: Nutrition is a key factor in healthy ageing but there are still gaps in knowledge about risk- and protective factors linking diet and healthy ageing. The aim of this study was to investigate time trends in dietary patterns and nutrient intake in an older population, in order to increase the understanding of whether dietary recommendations are followed and if nutrient needs are met.
\end{abstract}

Methods: Cross-sectional data was derived from five samples of 70-year-olds examined 1971-72, 1981-83, 1992-93, 2000-02 and 2014-16 from the Gothenburg H70 birth cohort studies in Sweden. A total of 2246 individuals (56\% women) participated. Dietary intake was determined by the diet history method, which is an interview including questions on usual frequencies and portion sizes of food intake during the preceding three months. Recommended values of nutrient intake and determinants of healthful dietary patterns were based on the Nordic Nutrition Recommendations 2012. Statistical analyses were performed using general linear models, student's t-test and chisquare test, stratified by sex.

Results: The intake of fruits and vegetables, fish and seafood, whole grain products and nuts and seeds increased during the study period $(p<0.0001)$, among both sexes. However, there was also an increase in alcohol intake $(p<0.0001)$, especially from wine and beer, and in 2014-16 more than 30\% had an alcohol intake above recommendations. Protein intake increased $(p<0.0001$ for women and $p=0.0004$ for men), and $48 \%$ of the women and $37 \%$ of the men had a protein intake above recommended $1.2 \mathrm{~g} / \mathrm{kg}$ body weight and day in 2014-16. The proportion of participants at risk of inadequate intake of vitamins $C, D$ and folate decreased during the study period, among both sexes $(p<0.0001)$. However, vitamin D intake from diet was still below average requirement level of $7.5 \mu \mathrm{g} /$ day for $49 \%$ of the women and $32 \%$ of the men in 2014-16.

(Continued on next page)

\footnotetext{
* Correspondence: jessica.samuelsson@neuro.gu.se

${ }^{1}$ Neuropsychiatric Epidemiology Unit, Department of Psychiatry and Neurochemistry, Institute of Neuroscience and Physiology, Sahlgrenska Academy, Centre for Ageing and Health (AgeCap) at the University of Gothenburg, Gothenburg, Sweden

Full list of author information is available at the end of the article
}

(c) The Author(s). 2019 Open Access This article is distributed under the terms of the Creative Commons Attribution 4.0 International License (http://creativecommons.org/licenses/by/4.0/), which permits unrestricted use, distribution, and reproduction in any medium, provided you give appropriate credit to the original author(s) and the source, provide a link to the Creative Commons license, and indicate if changes were made. The Creative Commons Public Domain Dedication waiver (http://creativecommons.org/publicdomain/zero/1.0/) applies to the data made available in this article, unless otherwise stated. 
(Continued from previous page)

Conclusions: Dietary patterns have changed among 70-year-olds during the past five decades, with an increase in healthful foods and a higher nutrient density in later born birth cohorts. However, the intake of alcohol increased, especially among women. Results from this study can be useful as a basis for dietary guidelines and used for prevention strategies involving older adults in population-based and health care settings.

Keywords: Dietary patterns, Macronutrients, Micronutrients, Energy intake, Nutrient intake, Older adults, Diet history, Time trends

\section{Background}

The average life expectancy is increasing world-wide and older adults constitute a growing proportion of the global population [1-3]. In Sweden, 20\% of the population is $\geq 65$ years of age, and by 2050 one in six worldwide, and one in four persons living in Europe and Northern America, is expected to be $\geq 65$. Non-communicable diseases (NCDs) account for most of the disease burden in older adults over 60 years of age (about 85\%), where cardiovascular diseases, cancer, diabetes and dementia account for approximately 50\% [4]. Many of these conditions can be prevented or delayed with a healthy lifestyle [5-9].

Healthy ageing is the process of developing and maintaining the functional ability that enables wellbeing in older age (World Health Organization definition) [10]. Nutrition is a key factor in healthy ageing $[9,11,12]$, but there are still gaps in knowledge about dietary patterns and nutrient intake among older adults, and whether intake is optimal in relation to recommendations in order to promote health and reduce the risk of NCDs $[8,13,14]$. Risk- and protective factors linking diet and healthy ageing can be identified by studying time trends of dietary intake in older populations, but these types of studies are rare. The Gothenburg H70 birth cohort studies in Sweden, have studied older adults since 1971 [15]. Previous results, up to 2000, indicate that later born birth cohorts have generally healthier dietary patterns, and that diet quality varies with level of education and occupation [16, 17]. A new birth cohort of 70-year-olds was added to the study in 2014 [18], which provides an opportunity to investigate time trends in dietary patterns and energy- and nutrient intake over nearly half a century in community-dwelling older adults.

The Nordic nutrition recommendations (NNR 2012) are developed to promote health and reduce the incidence of non-communicable diseases (NCD) [8]. The NNR 2012 are in line with global guidelines $[8,19-21]$, and form the basis for national dietary recommendations in the Nordic countries. These guidelines suggest that intake of foods, such as fruits and vegetables should be at least $500 \mathrm{~g} /$ day, that nuts and seeds and whole grain products should increase, and that fish and shellfish should be consumed 23 times a week. Further, they suggest that dairy products should be low in fat, and that intake of red and processed meat should be less than $500 \mathrm{~g} /$ week. They also suggest that alcohol intake should be less than $10 \mathrm{~g} /$ day for women and less than $20 \mathrm{~g} /$ day for men, and that salt and products high in added sugar should decrease in the population [8]. Comparing dietary intake among older adults with reference values from the NNR 2012 can increase our understanding of whether dietary recommendations are followed and if nutrient needs are met.

The primary aim of this study was to describe time trends in dietary patterns and energy- and nutrient intake in five population-based samples of 70-year-olds in the Gothenburg H70 birth cohort study, examined between 1971 and 2016. A secondary aim was to relate the results to the NNR 2012.

\section{Methods Samples}

Data was derived from the Gothenburg H70 Birth Cohort Studies and the Population Study of Women in Gothenburg (PPSW) $[15,18,22-24]$. The H70 study, which started in 1971, is a multidisciplinary epidemiological study examining a representative sample of older individuals, systematically recruited via the Swedish Population Register (Statistics Sweden). The studies include detailed personal examinations, assessing a large number of age-related risk and protective factors associated with the normal ageing processes [18].

This study has a serial cross-sectional design. It includes 70-year-olds who completed the dietary part of the examination performed in 1971-72 (birth cohort 1901-02), 1981-83 (birth cohort 1911-12), 1992-93 (birth cohort 1922), 2000-02 (birth cohort 1930) and 2014-16 (birth cohort 1944), as described in Fig. 1. Inability to remember and communicate dietary intake was exclusion criteria. The birth cohorts and characteristics of participants and non-participants have been described in detail previously $[16,18,25,26]$.

\section{Birth cohort 1901-02}

In 1971-72, all 70-year-olds living in Gothenburg and born 1901 and 1902 between July 1st, 1901 and June 30th, 1902, were systematically selected based on birthdates ending with 2,5 or $8(n=1148)$, as described 


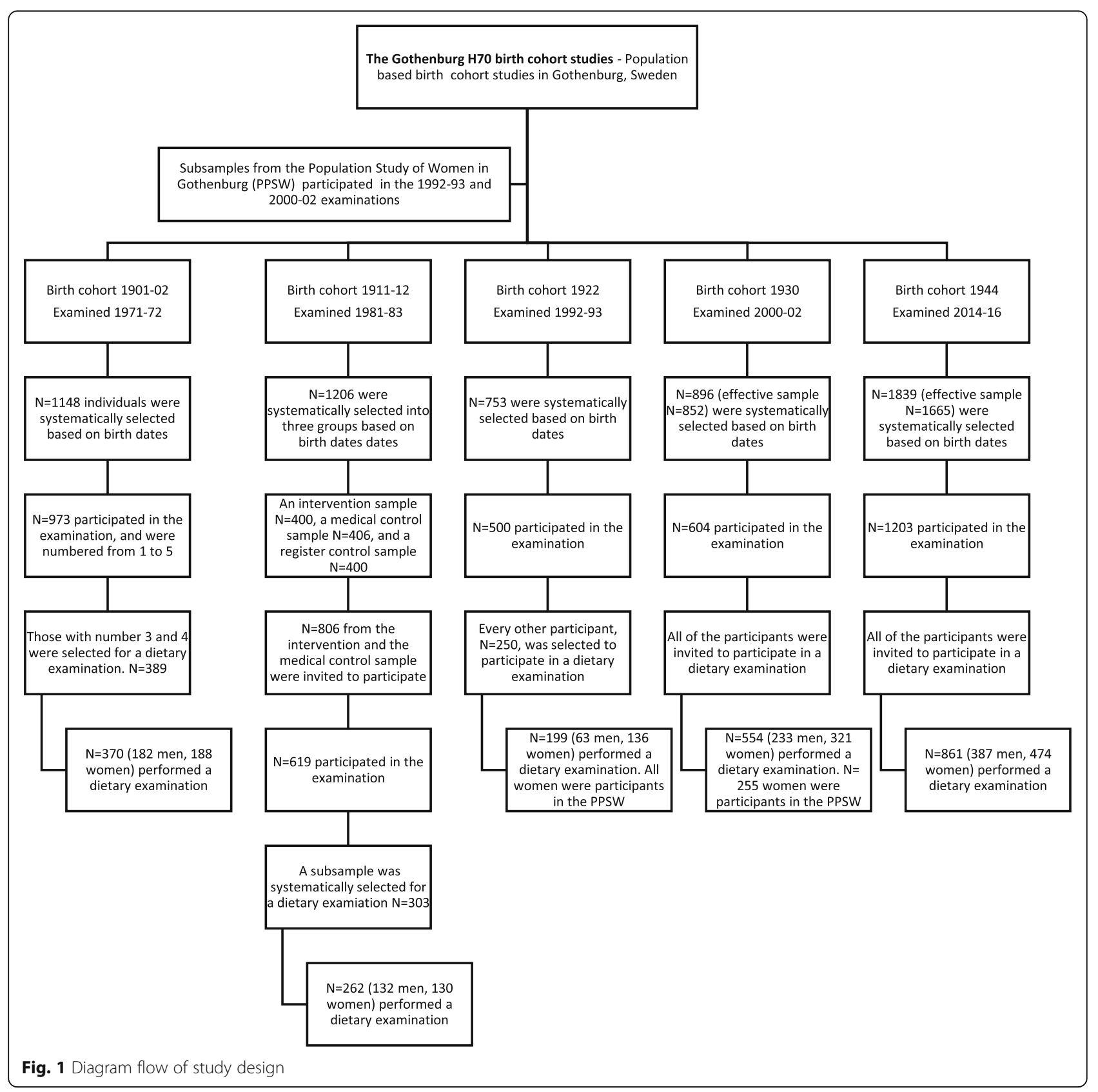

previously [15, 25]. Among these, 973 (response rate $85 \%)$ participated in the examination, and were numbered from 1 to 5 . Those with number 3 and 4 were selected for a dietary examination $(n=389)$. Among those, 370 (182 men, 188 women) performed a dietary examination, which took place in the participants' home.

\section{Birth cohort 1911-12}

In 1981-83, a population sample of 70-year-olds $(n=$ 1206) was systematically selected based in birth dates, as described previously [27]. The intervention concerned social, psychological, environmental and medical aspects in 400 participants, medical aspects alone in 406 participants and register control samples for 400 participants. A total of 619 (from the intervention and medical sample) participated in the examinations (response rate $77 \%)$. A subsample was systematically selected for the dietary examination $(n=303)$ [25]. Among those, 262 (132 men, 130 women) performed a dietary examination, which took place in the participants' home.

\section{Birth cohort 1922}

In 1992-93, all 70-year-olds living in Gothenburg and born 1922 on days $6,12,18,24,30$ of each month were 
invited to participate $(n=753)$, as described previously [24, 25, 28]. Among these, 500 participated (response rate $66 \%$ ) in the examination. A subsample of 250 were selected for a dietary examination. Among those, 199 (63 men, 136 women) participated in the dietary examination, which was performed in an outpatient hospital department, as part of the basic H70 examinations. The examination was a cooperation between the PPSW in Gothenburg and the H70-study. Thus, all of the women had previously taken part in the longitudinal PPSW.

\section{Birth cohort 1930}

In 2000-02, all 70-year-olds living in Gothenburg and born 1930 on days $6,12,18,24,30$ of each month were invited to participate $(n=896$, effective sample $n=852)$, as previously described $[16,24,26,28]$. A total of 604 (71\%) participated in the examination. All participants were scheduled for the dietary examination. Among those, 554 (233 men, 321 women) participated in the dietary examination, which was performed in an outpatient hospital department, as part of the basic H70 examinations. The examination was a cooperation between the PPSW in Gothenburg and the H70-study. Thus, 255 of the women had previously taken part in the longitudinal PPSW.

\section{Birth cohort 1944}

In the 2014-16, all 70-year-olds living in Gothenburg and born 1944 on dates ending with $0,2,5$, or 8 were invited to participate ( $n=1839$, effective sample $n=1665)$, as previously described [18]. A total of 1203 (72\%) participated in the examination. All participants were invited to take part of the dietary examination. Among those, 861 (387 men, 474 women) participated in the dietary examination, which was performed either at the participants home or in an outpatient hospital department (the participants could choose).

\section{Data collection}

\section{Dietary examination procedure}

The diet history $(\mathrm{DH})$ method was used in all five birth cohorts $[16-18,25,29]$, and results were therefore comparable. This DH has been validated and found to give estimated energy intakes comparable with energy requirements predicted by the heart rate method, activity diary and double labelled water method. However, with the double labelled water method, it was reported that the DH underestimated usual energy intake by $12 \%$. The underreporting of energy intake was mainly observed among overweight participants [30, 31].

The dietary examinations were semi-structured faceto-face interviews, estimating dietary intake during the preceding three months. The protocols for the interviews consist of a meal-pattern interview, accompanied by a food list with questions on usual frequencies and portion sizes of foods. Dietary intake in the 2014-16 examination was registered as gram of food items usually consumed per day/week/month in a customized (for this study) version of the computer program Dietist Net [32] containing the Swedish National Food Agency's (NFA) nutrient database of 2015. Pictures of foods, containing portion sizes, from NFA were used during the interviews. The previous examinations were registered in the same way and calculated in the NFA's nutrient database (PC-kost) in 2000-02 [16]. The dietary examinations have been described in detail previously $[16,18,25]$. Trained dietitians performed the interviews in all of the five birth cohorts.

\section{Dietary assessments}

To evaluate potential underreporting of energy intake in this study, the Goldberg method was used [33]. Energy intake (EI) in megajoul (MJ) was divided with calculated basal metabolic rate (BMR) values [33]. Equations for adults aged 60-74 years were used to calculate the participants BMR values; 0.0386 *body weight $(\mathrm{kg})+2.88$, for women and $0.0499^{*}$ body weight $(\mathrm{kg})+2.93$, for men [31]. For individuals in energy balance, their EI/BMR value should equal their physical activity level (PAL). A PAL value of $1.35^{*} \mathrm{BMR}$ is considered the minimum energy expenditure compatible with a normal active lifestyle [34]. An EI/BMR value of 1.35 was therefore set as the cut-off value to determine potential underreporting of energy intake in this study [33,34].

Percentages of energy (E\%) from carbohydrate-, protein-, fat-, fibre- and alcohol intake were calculated. Recommended intervals of $E \%$ intake, from each macronutrient, were based on the NNR 2012 recommendations [8].

An alcohol intake of $10 \mathrm{~g} /$ day for women, and $20 \mathrm{~g} /$ day for men, was set as cut-off values to investigate the proportions that had an intake above recommended intake [8].

Protein intake $/ \mathrm{kg}$ body weight and day was calculated by dividing gram of protein intake/day with body weight (BW) in $\mathrm{kg}$ [35]. A protein intake of $1.2 \mathrm{~g} / \mathrm{kg} \mathrm{BW}$ was set as cut-off value to investigate the proportions above recommended intake [8].

Calculations of energy from fibre has varied during the last five decades (from 0 to $4 \mathrm{kcal} / \mathrm{gram}$ fibre) [36]. In this study, energy from fibre was calculated according to the National Food Agency's (NFA) database [37] by multiplying gram of fibre intake with $1.91 \mathrm{kcal}$, for all birth cohorts.

The NNR 2012 recommended intake values (RI) of vitamins and minerals include safety margins for individual variations. However, intakes between average requirement (AR) and RI levels are considered adequate 
[8]. AR levels for vitamin- and mineral intake were set as cut-off values to assess the risk for inadequate intake in this study.

Registered food intake was divided into 35 food groups (Additional file 1) in accordance with the NFA's study on dietary patterns [38], with a special focus on healthrelated foods such as vegetables and pulses, fruits and berries, nuts and seeds, fish and shellfish, red and processed meat, dairy products, cereals, sweets, sweet beverages and alcohol intake [8].

Intake of nutritional supplements was not included in this study.

\section{Sample characteristics}

Educational level was dichotomized into compulsory primary education versus more than that 6 years in those born 1901-02, 1911-12 and 1922, 7 years in those born 1930, and 9 years in those born 1944). Smoking was dichotomized into smoker (current) or non-smoker (never smoked or past smoker). Living situation was dichotomized into institutionalized (hospitalized or otherwise institutionalized) or living in a home environment (i.e. own home or as a lodger). Marital status was dichotomized into married (currently married and/or cohabiting) or not married (never been married/not cohabiting, divorced, widowed). Physical activity level was divided into three groups; sedentary lifestyle (sedentary/low physical activity level), moderate physical activity level (low to moderate), high activity level (moderate to high). Body mass index (BMI) was calculated based on measured height and weight values $\left(\mathrm{kg} / \mathrm{m}^{2}\right)$.

The Strobe-Nut checklist was used during the writing process, see Additional file $2[39,40]$.

\section{Statistical analysis}

All analyses were calculated stratified by sex. Normality tests were conducted using Shapiro-Wilk test, histogram and Normal Q-Q plot tests.

Values were expressed as means and standard deviations. General linear regressions were performed to examine time trends during the study period, with mean BMI, EI/BMR, E\% intake from macronutrient-, energy-, nutrient- and food group values as dependent variables and years of each birth cohort as independent variables. Student's t-test was performed to compare mean values of BMI, EI/BMR, E\% intake from macronutrients, and energy-, nutrient-, and food intake levels between birth cohorts. The distribution of some of the variables was not normal, and for this reason alcohol-, micronutrientand food intake values were log-transformed (Lg10) to normalise the data. For transforming alcohol and food intake, a value of $1 \mathrm{~g}$ was added to zero for foods never consumed. The log-transformed data was used in the linear regression analyses.
Birth cohort 1901-02 was excluded in the analyses of alcohol intake, since questions about beer, wine and spirits were not comparable in 1971-72. Beer intake was included in energy, alcohol and nutrient group means in 1971-72, but wine and spirit intake was not (no data of gram intake). Birth cohort 1944 was excluded in the analyses of margarine-, butter- and vegetable oil intake, since cooking fat was included in prepared dishes in 2014-16 and not registered separately as in previous cohorts. Cooking fat was included in energy and nutrient group means for all birth cohorts.

Chi-square tests were performed to evaluate potential differences in the following characteristics: the distribution of participants with an E\% intake from macronutrients within the NNR 2012 recommendations, the distribution of participants with a micronutrient intake above AR; and the distribution of consumers in each food group.

To investigate effects of potential underreporting of energy intake, additional sensitivity analyses were performed by excluding participants with an EI/BMR $<1.35$ in the linear regressions of macro- and micronutrients.

Pearson correlation analyses were performed between EI/BMR and BMI values within each birth cohort.

The statistical analyses were performed using IBM SPSS STATISTICS 24. All statistical tests were two-tailed and $p$-values of $<0.05$ were considered statistically significant.

\section{Results}

\section{Characteristics of participants}

Sample characteristics are given in Table 1. There was a linear increase in mean BMI (from 25 to 26) among men during the study period ( $p=0.012$ ), and an increase in BMI (from 26 to 27) between 1971 and 72 and 200002 among women $(p=0.019)$. However, BMI among both women $(\mathrm{p}=<0.0001)$ and men $(p=0.038)$ decreased between 2000-02 and 2014-16 (from 27 to 26). Prevalence of smoking decreased (from 12 to $9 \%$ among women and 46 to $7 \%$ among men), physical activity level increased (those with a sedentary life style decreased from 20 to $3 \%$ among women and 12 to $3 \%$ among men) and educational level increased (those with only compulsory education or less decreased from 84 to $11 \%$ among women and 81 to $15 \%$ among men), during the study period. The majority of participants were communitydwelling ( 0 to $4 \%$ were institutionalized during the study period). The proportion married increased among women (from 47 to $60 \%$ ), but not among men (79-81\%), during the study period.

\section{Time trends of energy- and nutrient intake and El/BMR values}

Mean energy-, macro- and micronutrient intake and EI/ BMR values, in relation to birth cohorts, are given in 
Table 1 Sample characteristics of participants, stratified by sex and birth cohorts

\begin{tabular}{|c|c|c|c|c|c|c|}
\hline Birth cohort & $1901-02(n=370)$ & $1911-12(n=262)$ & $1922(n=199)$ & $1930(n=554)$ & $1944(n=861)$ & \\
\hline Examination years & $1971-72$ & $1981-83$ & 1992-93 & 2000-02 & 2014-16 & \\
\hline Women total $n$ & 188 & 130 & 136 & 321 & 474 & $\begin{array}{l}\text { Linear } \\
\text { trend }\end{array}$ \\
\hline $\mathrm{BM}{ }^{*}\left(\mathrm{~kg} / \mathrm{m}^{2}\right)$ & & & & & & $P$ value \\
\hline \multirow[t]{2}{*}{ Mean $\pm(S D)$} & $26,1(4,2)$ & $27,1(4,6)$ & $26,1(4,3)$ & $27,1(4,5)$ & $25,6(5,0)$ & 0.084 \\
\hline & $\begin{array}{l}\% \text { (no. of cases/total } \\
\text { cases) }\end{array}$ & $\begin{array}{l}\% \text { (no. of cases/total } \\
\text { cases) }\end{array}$ & $\begin{array}{l}\% \text { (no. of cases/total } \\
\text { cases) }\end{array}$ & $\begin{array}{l}\% \text { (no. of cases/total } \\
\text { cases) }\end{array}$ & $\begin{array}{l}\% \text { (no. of cases/total } \\
\text { cases) }\end{array}$ & $\begin{array}{l}X^{2} \\
P \text { value }\end{array}$ \\
\hline \multicolumn{7}{|l|}{ Living situation } \\
\hline Institutionalized & $4(7 / 188)$ & $0(0 / 130)$ & $2(3 / 136)$ & $1(2 / 317)$ & $1(6 / 465)$ & 0.029 \\
\hline \multicolumn{7}{|l|}{ Physical activity level } \\
\hline $\begin{array}{l}\text { Sedentary } \\
\text { lifestyle }\end{array}$ & $20(38 / 187)$ & $31(39 / 128)$ & $22(30 / 136)$ & $8(25 / 314)$ & $3(14 / 467)$ & $<0.0001$ \\
\hline \multicolumn{7}{|l|}{ Smoking } \\
\hline Current smoker & $12(22 / 188)$ & $12(16 / 130)$ & $24(32 / 135)$ & $15(48 / 316)$ & $9(41 / 471)$ & 0.0001 \\
\hline \multicolumn{7}{|l|}{ Educational level } \\
\hline $\begin{array}{l}\leq \text { Primary } \\
\text { school }\end{array}$ & $84(157 / 186)$ & $78(101 / 129)$ & $62(80 / 129)$ & $64(202 / 317)$ & $11(50 / 469)$ & $<0.0001$ \\
\hline \multicolumn{7}{|l|}{ Marital status } \\
\hline Married & $47(88 / 188)$ & $52(68 / 130)$ & $51(69 / 136)$ & $50(158 / 317)$ & $60(280 / 467)$ & 0.009 \\
\hline Men total $n$ & 182 & 132 & 63 & 233 & 387 & $\begin{array}{l}\text { Linear } \\
\text { trend }\end{array}$ \\
\hline$B M l^{*}\left(\mathrm{~kg} / \mathrm{m}^{2}\right)$ & & & & & & P value \\
\hline \multirow[t]{2}{*}{ Mean $\pm(S D)$} & $25,5(3,3)$ & $25,8(3,6)$ & $26,9(3,9)$ & $26,9(3,9)$ & $26,2(4,0)$ & 0.012 \\
\hline & $\begin{array}{l}\% \text { (no. of cases/total } \\
\text { cases) }\end{array}$ & $\begin{array}{l}\% \text { (no. of cases/total } \\
\text { cases) }\end{array}$ & $\begin{array}{l}\% \text { (no. of cases/total } \\
\text { cases) }\end{array}$ & $\begin{array}{l}\% \text { (no. of cases/total } \\
\text { cases) }\end{array}$ & $\begin{array}{l}\% \text { (no. of cases/total } \\
\text { cases) }\end{array}$ & $\stackrel{X^{2}}{P}$ value \\
\hline \multicolumn{7}{|l|}{ Living situation } \\
\hline Institutionalized & $2(3 / 182)$ & $0(0 / 132)$ & $3(2 / 63)$ & $0(0 / 232)$ & $2(6 / 386)$ & 0.102 \\
\hline \multicolumn{7}{|l|}{ Physical activity level } \\
\hline $\begin{array}{l}\text { Sedentary } \\
\text { lifestyle }\end{array}$ & $12(21 / 182)$ & $15(20 / 130)$ & $18(11 / 63)$ & $10(22 / 226)$ & $3(10 / 381)$ & $<0.0001$ \\
\hline \multicolumn{7}{|l|}{ Smoking } \\
\hline Current smoker & $46(84 / 182)$ & $33(43 / 132)$ & $25(16 / 63)$ & $14(33 / 229)$ & $7(26 / 387)$ & $<0.0001$ \\
\hline \multicolumn{7}{|l|}{ Education } \\
\hline $\begin{array}{l}\text { < Primary } \\
\text { school }\end{array}$ & $81(147 / 181)$ & $71(94 / 130)$ & $53(18 / 34)$ & $57(132 / 231)$ & $15(59 / 382)$ & $<0.0001$ \\
\hline \multicolumn{7}{|l|}{ Marital status } \\
\hline Married & $79(142 / 181)$ & $76(100 / 132)$ & $68(43 / 63)$ & $74(173 / 232)$ & $81(310 / 382)$ & 0.112 \\
\hline
\end{tabular}

*There were missing body mass index (BMI) data for four men in 1992-93 and one in 2000-02, among women, there were missing BMI data for one individual in 1981-83, six in 1992-93, three in 2000-02 and two in 2014-16

Table 2. Mean EI/BMR values were above the cut-off value of 1.35 among both sexes at all examinations. There was a negative correlation between BMI and EI/ BMR values (correlation range between $-0.324, \mathrm{r}^{2} 0.11$ and $-0.535, \mathrm{r}^{2} 0.29, p=0.01$ ) among both sexes during the study period, indicating that participants with a higher BMI were more likely than other participants to underreport their energy intake.
There was a linear increase in mean energy intake among women during the study period, while there was an increase between 1971 and 72 and 2000-01 ( $p<$ 0.0001 ) and a decrease between 2000 and 02 and 201416 among men $(\mathrm{p}<0.0001)$.

Regarding macronutrients, there was a linear increase in mean protein intake, protein intake $/ \mathrm{kg} \mathrm{BW}$ and fibre intake, and a decrease in carbohydrate intake among 
Table 2 Time trends of El/BMR-values, mean energy- and nutrient intake per day and comparisons between birth cohorts

\begin{tabular}{|c|c|c|c|c|c|c|c|}
\hline Birth cohort & $1901-02$ & $1911-12$ & 1922 & 1930 & 1944 & & \\
\hline Examination years & 1971-72 & $1981-83$ & 1992-93 & 2000-02 & 2014-16 & & \\
\hline Women & $n=188$ & $n=130$ & $n=136$ & $n=321$ & $n=474$ & Linear trend & Recommended daily intake* \\
\hline Daily intake (except El/BMR) & Mean (SD) & Mean (SD) & Mean (SD) & Mean (SD) & Mean (SD) & $P$ value & \\
\hline $\mathrm{El}^{\mathrm{BMMR}}{ }^{1}$ & $1.44(0.44)$ & $1.50(0.40)$ & $1.44(0.38)$ & $1.48(0.38)$ & $1.52(0.37)^{\mathrm{j} r}$ & 0.022 & \\
\hline Energy (kcal) & $1869(512)$ & $1974(509)$ & $1885(458)$ & $1970(472)^{a}$ & $2006(453)^{\mathrm{a} j}$ & 0.001 & \\
\hline Protein (g) & $67(17)$ & $70(19)$ & $76(18)^{a} \mathrm{~h}$ & $77(19)^{a} \mathrm{~h}$ & $84(22)^{\text {a h j r }}$ & $<0.0001$ & \\
\hline Protein $(\mathrm{g} / \mathrm{kg} \mathrm{BW})^{1}$ & $1.03(0.32)$ & $1.04(0.32)$ & $1.13(0.32)^{a \mathrm{~h}}$ & $1.11(0.32)^{a \mathrm{~h}}$ & $1.24(0.38)^{a ~ h ~ j ~ r ~}$ & $<0.0001$ & $1,20 \mathrm{~g} / \mathrm{kg} \mathrm{BW}$ \\
\hline Fat (g) & $75(25)$ & $82(25)^{\mathrm{a}}$ & $74(25)^{\mathrm{h}}$ & $76(26)^{\mathrm{h}}$ & $83(26)^{\text {a j r }}$ & 0.001 & \\
\hline Carbohydrates (g) & $219(65)$ & $226(64)$ & $213(58)$ & $226(61)^{\mathrm{j}}$ & $202(59)^{\mathrm{a} \mathrm{h} \mathrm{r}}$ & 0.0001 & \\
\hline Alcohol $(g)^{2}$ & $1(2)$ & $2(4)$ & $4(7)$ & $5(6)^{h}$ & $9(10)^{h j ~ j ~}$ & $<0.0001$ & $<10$ \\
\hline Fibre (g) & $16(5)$ & $19(6)^{a}$ & $20(7)^{a}$ & $21(7)^{\mathrm{a} \mathrm{h} \mathrm{j}}$ & $25(8)^{a h ~ j ~ r ~}$ & $<0.0001$ & $25-30$ \\
\hline Vitamin D $(\mu \mathrm{g})$ & $5.6(2.2)$ & $5.1(1.8)^{a}$ & $6.4(3.0)^{a} \mathrm{~h}$ & $6.5(2.8)^{a \mathrm{~h}}$ & $8.3(3.8)^{\mathrm{a} \mathrm{h} \mathrm{j} \mathrm{r}}$ & $<0.0001$ & 10 \\
\hline Vitamin C (mg) & $93(55)$ & $83(44)$ & $112(70)^{a ~ h}$ & $128(68)^{\mathrm{a} \mathrm{h} \mathrm{j}}$ & $152(78)^{a \mathrm{~h} \mathrm{j} \mathrm{r}}$ & $<0.0001$ & 75 \\
\hline $\mathrm{B} 12(\mu \mathrm{g})$ & $10.0(6.0)$ & $7.6(5.5)^{a}$ & $9.5(9.0)^{\mathrm{h}}$ & $6.5(4.0)^{\mathrm{a} j}$ & $6.5(3.0)^{\mathrm{ah} \mathrm{j}}$ & $<0.0001$ & 2 \\
\hline Folate $(\mu \mathrm{g})$ & $207(63)$ & $211(61)$ & $250(100)^{a} \mathrm{~h}$ & $264(79)^{a} \mathrm{~h}$ & $347(114)^{a h ~ j ~ r ~}$ & $<0.0001$ & 300 \\
\hline Iron (mg) & $13(4)$ & $12(4)^{a}$ & $12(4)$ & $12(3)$ & $12(3)^{a}$ & 0.077 & 9 \\
\hline Calcium (mg) & 928 (348) & $1025(367)^{a}$ & $1058(374)^{a}$ & $1055(393)^{a}$ & $1028(399)^{a}$ & 0.003 & 800 \\
\hline Men & $n=182$ & $n=132$ & $n=63$ & $n=233$ & $n=387$ & & \\
\hline $\mathrm{El} \mathrm{BMR}^{1}$ & $1.42(0.35)$ & $1.59(0.43)^{\mathrm{a}}$ & $1.45(0.45)^{\mathrm{n}}$ & $1.56(0.42)^{\mathrm{a}}$ & $1.40(0.34)^{r}$ & 0.095 & \\
\hline Energy (kcal) & $2290(546)$ & $2555(644)^{a}$ & $2402(707)$ & $2603(659)^{a} \mathrm{j}$ & $2358(519)^{\mathrm{h} r}$ & 0.538 & \\
\hline Protein (g) & $80(20)$ & $86(22)^{a}$ & $94(26)^{a} \mathrm{~h}$ & $98(25)^{a \mathrm{~h}}$ & $95(23)$ a h & $<0.0001$ & \\
\hline Protein $(\mathrm{g} / \mathrm{kg} \mathrm{BW})^{1}$ & $1.06(0.28)$ & $1.13(0.34)^{\mathrm{a}}$ & $1.16(0.33)^{\mathrm{a}}$ & $1.21(0.35)^{\mathrm{a}}$ & $1.16(0.33)^{a}$ & 0.0004 & $1,20 \mathrm{~g} / \mathrm{kg} \mathrm{BW}$ \\
\hline Fat (g) & $92(27)$ & $106(34)^{a}$ & $91(30)^{\mathrm{h}}$ & $101(36)^{a}$ & $96(29)^{\mathrm{h}}$ & 0.597 & \\
\hline Carbohydrates (g) & $268(70)$ & $288(76)^{a}$ & $274(101)$ & $289(83)^{a}$ & $236(67)$ a h j r & $<0.0001$ & \\
\hline Alcohol $(g)^{2}$ & $5(5)$ & $9(13)$ & $9(11)$ & $13(15)^{\mathrm{h} \mathrm{j}}$ & $17(17)^{\mathrm{hj} \mathrm{r}}$ & $<0.0001$ & $<20$ \\
\hline Fibre (g) & $19(6)$ & $22(8)^{a}$ & $22(8)^{a}$ & $24(8)^{a} \mathrm{~h}$ & 27 (9) a h j r & $<0.0001$ & $25-30$ \\
\hline Vitamin D $(\mu \mathrm{g})$ & $6.7(2.5)$ & $6.4(2.5)$ & $8.1(3.2)^{a} \mathrm{~h}$ & $8.4(3.5)^{a \mathrm{~h}}$ & $9.6(4.7)$ a h j r & $<0.0001$ & 10 \\
\hline Vitamin C (mg) & $85(45)$ & $84(42)$ & $100(56)^{\mathrm{h}}$ & $129(80)^{a \mathrm{~h} \mathrm{j}}$ & $147(85)$ a h j r & $<0.0001$ & 75 \\
\hline $\mathrm{B} 12(\mu \mathrm{g})$ & $10.9(6.1)$ & $8.0(4.3)^{a}$ & $12.8(9.2)^{\mathrm{h}}$ & $8.7(5.8)^{a} \mathrm{j}$ & $7.8(4.1)$ a j r & $<0.0001$ & 2 \\
\hline Folate $(\mu \mathrm{g})$ & $230(59)$ & $245(74)$ & $268(83)^{a}$ & $301(107)^{a \mathrm{~h} \mathrm{j}}$ & $356(116)$ a hjr & $<0.0001$ & 300 \\
\hline Iron (mg) & $15(5)$ & $16(5)$ & $16(6)$ & $16(4)$ & $13(3)$ a h j r & $<0.0001$ & 9 \\
\hline Calcium (mg) & 1051 (393) & $1217(450)^{a}$ & $1170(400)^{a}$ & $1312(557)^{a j}$ & $1059(411)^{\mathrm{h} \mathrm{j} \mathrm{r}}$ & 0.901 & 800 \\
\hline
\end{tabular}

*Based on the Nordic nutrition recommendations 2012

${ }^{1}$ There were missing protein/kgBW (body weight) and El/BMR values, due to missing weight data, for one women in birth cohort 1911, five in birth cohort 1922, three in birth cohort 1930, two in birth cohort 1944 and four men in birth cohort 1922 and one man in birth cohort 1930

${ }^{2}$ Linear trends in alcohol intake are based on data from 1981 to 2016

aSignificant difference compared with birth cohort1901-02

nSignificant difference compared with birth cohort 1911-12

significant difference compared with birth cohort 1922

'Significant difference compared with birth cohort1930

both sexes, during the study period. The change in carbohydrate intake was mainly due to a decreased intake between 2000-02 and 2014-16 ( $\mathrm{p}<0.0001)$. There was a linear increase in mean fat intake among women, but not among men.

The proportion with a recommended intake of more than $1.2 \mathrm{~g}$ protein $/ \mathrm{kg}$ BW was $28 \%$ in $1971-72,26 \%$ in
$1981-83,31 \%$ in $1992-93,32 \%$ in $2000-02$, and $48 \%$ in 2014-16 among women. Among men, the proportions were $28 \%$ in $1971-72$, $36 \%$ in $1981-83,41 \%$ in $1992-93$, $47 \%$ in $2000-02$, and $37 \%$ in $2014-16$.

Regarding micronutrients, there was a linear increase in mean folate-, vitamin D- and C intake, and a decrease in vitamin B12 intake among both sexes, during the 
Table 3 Distribution of participants with a micronutrient intake above average requirement intake (>AR)

\begin{tabular}{|c|c|c|c|c|c|c|c|c|c|c|c|c|c|c|}
\hline $\begin{array}{l}\text { Birth cohort } \\
\text { Examination } \\
\text { years }\end{array}$ & & 1901-02 & $1911-12$ & 1922 & 1930 & 1944 & & & $1901-02$ & $1911-12$ & 1922 & 1930 & 1944 & \\
\hline \multirow{3}{*}{$\begin{array}{l}\text { Examination } \\
\text { years }\end{array}$} & & $1971-72$ & $1981-83$ & 1992-93 & $2000-02$ & 2014-16 & & & $1971-72$ & $1981-83$ & 1992-93 & $2000-02$ & 2014-16 & \\
\hline & Women & $\mathrm{n}=188$ & $n=130$ & $n=136$ & $n=321$ & $n=474$ & $x^{2}$ & Men & $\mathrm{n}=182$ & $n=132$ & $n=63$ & $n=233$ & $n=387$ & $x^{2}$ \\
\hline & $>A R$ & n (\%) & n (\%) & n (\%) & n (\%) & n (\%) & $P$ value & $>A R$ & n (\%) & n (\%) & n (\%) & n (\%) & n (\%) & $P$ value \\
\hline $\begin{array}{l}\text { Vitamin D } \\
(\mu \mathrm{g})\end{array}$ & $>7.5 \mu \mathrm{g}$ & $36(19)$ & $16(12)$ & $32(23)$ & $94(29)$ & $244(51)$ & $<0.0001$ & $>7.5 \mu \mathrm{g}$ & $61(33)$ & $38(29)$ & $29(46)$ & $127(54)$ & $262(68)$ & $<0.0001$ \\
\hline $\begin{array}{l}\text { Vitamin C } \\
\text { (mg) }\end{array}$ & $>50 \mathrm{mg}$ & 147 (78) & $100(77)$ & 113 (83) & $289(90)$ & $452(95)$ & $<0.0001$ & $>60 \mathrm{mg}$ & 119 (65) & $81(61)$ & $45(71)$ & $192(82)$ & $348(90)$ & $<0.0001$ \\
\hline B12 ( $\mu \mathrm{g})$ & $>1.4 \mu \mathrm{g}$ & $188(100)$ & $129(99)$ & 135 (99) & $320(99)$ & $474(100)$ & 0.334 & $>1.4 \mu \mathrm{g}$ & $\begin{array}{l}182 \\
(100)\end{array}$ & $\begin{array}{l}132 \\
(100)\end{array}$ & $63(100)$ & $\begin{array}{l}233 \\
(100)\end{array}$ & $\begin{array}{l}387 \\
(100)\end{array}$ & 0.839 \\
\hline Folate $(\mu \mathrm{g})$ & $>200 \mu \mathrm{g}$ & $93(49)$ & $69(53)$ & $87(64)$ & $253(79)$ & 448 (94) & $<0.0001$ & $>200 \mu \mathrm{g}$ & $127(70)$ & $93(70)$ & $51(81)$ & $205(88)$ & 365 (94) & $<0.0001$ \\
\hline Iron (mg) & $>6 \mathrm{mg}$ & 184 (98) & $126(97)$ & 135 (99) & $318(99)$ & 457 (96) & 0.094 & $>7 \mathrm{mg}$ & 178 (98) & $128(97)$ & $63(100)$ & $232(99)$ & $380(98)$ & 0.260 \\
\hline Calcium (mg) & $>500 \mathrm{mg}$ & $170(90)$ & $124(95)$ & $132(97)$ & $312(97)$ & $463(98)$ & 0.0003 & $>500 \mathrm{mg}$ & $171(94)$ & $127(96)$ & $60(95)$ & $228(98)$ & $377(97)$ & 0.187 \\
\hline
\end{tabular}

study period. There was a linear decrease in mean iron intake among men, but not among women, and a linear increase in mean calcium intake among women, but not among men.

Results from sensitivity analyses, excluding participants with $\mathrm{EI} / \mathrm{BMR}$ values $<1$. 35, indicated the same linear trends for differences in macro- and micronutrient intake between birth cohorts as for the total population, except for fat-, calcium- (trends were no longer significant) and iron (decreased, $\mathrm{p}=<0.0001$ ) intake among women.

The distribution of participants that were more likely to have an adequate micronutrient intake above average requirement $(>\mathrm{AR})$ is shown in Table 3 . The proportion of participants with an $>A R$ intake of vitamin $D$, vitamin $\mathrm{C}$ and folate increased among both sexes during the study period. The proportion participants with an $>A R$ intake of calcium increased among women, but not among men. The majority of participants (range 96$100 \%$ ) had a B12 and iron intake $>$ AR at all examinations, among both sexes.

Mean E\% intake and E\% distribution of macronutrients and alcohol are given in Table 4. There was a linear increase in mean $\mathrm{E} \%$ intake from protein, alcohol and fibre, and a decrease in E\% intake from carbohydrates among both sexes, during the study period. There was no linear trend for changed mean E\% intake from fat, either among women or men. The proportions with an E\% intake according to the NNR 2012 recommendations, increased for protein intake, and decreased for fat-, carbohydrate- and alcohol intake among both sexes, during the study period.

\section{Time trends in food- and beverage intake}

Mean food and beverage intake, in relation to birth cohorts, are given in Table 5. There was a linear increase in intake of vegetables and pulses, fruits and berries, nuts and seeds, fish and shellfish among both sexes, during the study period. There was a linear increase in red and processed meat intake among women during the study period, while there was an increase only between 1971 and 72 and 2000-02 among men $(p<0.0001)$. However, mean intake of red and processed meat decreased between 2000-02 and 2014-16, among both women $(p=0.004)$ and men $(p=0.012)$. There was a linear decrease in intake of keyhole (low-fat/low sugar) milk products (milk, sour milk and yoghurt) and non-keyhole (semi/full-fat and sweetened) milk products among women, during the study period. This trend was not observed among men. However, the intake of keyhole milk products decreased between 2000-02 and 2014-16 among men ( $<<0.0001)$. There was a linear increase in intake of cream and crème fraiche, cheese, pasta, rice and food grains and fibrerich (>5\% fibre) bread, and a decrease in intake of cereals and refined bread ( $\leq 5 \%$ fibre) among both sexes, during the study period.

There was a linear increase in intake of sweets (e. g. candy, chocolate) and snacks (e. g. crisps, popcorn, cheese doodles), and a decrease in intake of sweet bakery (e. g. buns, cookies, cakes) and sweet condiments (e. g. sugar, honey, jam) among both sexes, during the study period. Among women, but not among men, there was also a decrease in intake of desserts (e. g. sweet pie, ice cream, chocolate mousse), during the study period.

There was a linear increase in juice (fruit- and vegetable juices) intake, and a decrease in soda (soft drinks, lemonade) intake among both sexes, during the study period. However, among women, there was a decrease in juice intake between 2000-02 and 2014-16, and the linear decrease in soda was mainly due to a decreased intake between 2000-02 and 2014-16, among both sexes $(p<0.0001)$.

The proportions of participants who consumed different foods and beverages are given in Table 6. Consumers of vegetables and pulses, fruits and berries, fish and shellfish, red and processed meat ranged from 94 to $100 \%$ during the study period, while consumers of nuts 
Table 4 Distribution of energy percent (E\%) intake from protein, fat, carbohydrate, fibre and alcohol

\begin{tabular}{|c|c|c|c|c|c|c|c|c|c|c|c|c|c|}
\hline Birth cohort & \multicolumn{2}{|c|}{$1901-02$} & \multicolumn{2}{|c|}{$1911-12$} & \multicolumn{2}{|l|}{1922} & \multicolumn{2}{|l|}{1930} & \multicolumn{5}{|l|}{1944} \\
\hline Examination years & \multicolumn{2}{|c|}{ 1971-72 } & \multicolumn{2}{|c|}{$1981-83$} & \multicolumn{2}{|c|}{ 1992-93 } & \multicolumn{2}{|c|}{ 2000-02 } & \multicolumn{3}{|c|}{ 2014-16 } & & \\
\hline \multirow[t]{2}{*}{ Women } & $\begin{array}{l}n= \\
188\end{array}$ & $\begin{array}{l}\text { within } \\
\text { NNR rec. }\end{array}$ & $\begin{array}{l}n= \\
130\end{array}$ & $\begin{array}{l}\text { within } \\
\text { NNR rec. }\end{array}$ & $\begin{array}{l}n= \\
136\end{array}$ & $\begin{array}{l}\text { within } \\
\text { NNR rec. }\end{array}$ & $\begin{array}{l}n= \\
321\end{array}$ & $\begin{array}{l}\text { within } \\
\text { NNR rec. }\end{array}$ & $\begin{array}{l}n= \\
474\end{array}$ & $\begin{array}{l}\text { within } \\
\text { NNR rec. }\end{array}$ & $\begin{array}{l}\text { Linear } \\
\text { trend }\end{array}$ & $\begin{array}{l}x^{2} \text { within } \\
\text { NNR rec. }\end{array}$ & $\begin{array}{l}\text { Recommended } \\
\text { E\% intake* }\end{array}$ \\
\hline & $\begin{array}{l}\text { Mean } \\
\text { (SD) }\end{array}$ & $\%$ & $\begin{array}{l}\text { Mean } \\
(\mathrm{SD})\end{array}$ & $\%$ & $\begin{array}{l}\text { Mean } \\
(\mathrm{SD})\end{array}$ & $\%$ & $\begin{array}{l}\text { Mean } \\
(\mathrm{SD})\end{array}$ & $\%$ & $\begin{array}{l}\text { Mean } \\
\text { (SD) }\end{array}$ & $\%$ & $P$ value & $P$ value $\%$ & \\
\hline Protein E\% & $15(2)$ & 33 & $14(2)$ & 33 & ${ }_{h}^{16(3)^{a}}$ & 57 & ${ }_{h}^{16(3)^{a}}$ & 52 & $\begin{array}{l}17(3)^{a} \\
h \text { j r }\end{array}$ & 60 & $\begin{array}{l}< \\
0.0001\end{array}$ & $<0.0001$ & $15-20$ \\
\hline Fat E\% & $36(6)$ & 76 & $37(5)$ & 72 & $35(6)^{\mathrm{h}}$ & 77 & $\begin{array}{l}34(6)^{a} \\
h\end{array}$ & 77 & $\begin{array}{l}37(7)^{a} \\
j \mathrm{r}\end{array}$ & 67 & 0.132 & 0.007 & $25-40$ \\
\hline $\begin{array}{l}\text { Carbohydrates } \\
\text { E\% }\end{array}$ & $47(6)$ & 65 & $46(5)^{a}$ & 55 & $45(6)^{a}$ & 53 & $46(6)^{a}$ & 58 & $\begin{array}{l}40(7)^{a} \\
h r j\end{array}$ & 23 & $\begin{array}{l}< \\
0.0001\end{array}$ & $<0.0001$ & $45-60$ \\
\hline Alcohol E\% & $0(1)$ & 100 & $1(1)^{\mathrm{a}}$ & 96 & $2(3)^{a}$ & 96 & $\ln _{h}^{2(2)^{a}}$ & 92 & $\begin{array}{l}3(4)^{a} \\
h j r\end{array}$ & 79 & $\begin{array}{l}< \\
0.0001\end{array}$ & $<0.0001$ & $<5$ \\
\hline Fibre E\% & $2(1)$ & & $2(0.5)$ & & $2(1)$ & & $2(1)$ & & $3(1)$ & & $\begin{array}{l}< \\
0.0001\end{array}$ & & No rec. \\
\hline Men & $\begin{array}{l}n= \\
182\end{array}$ & & $\begin{array}{l}n= \\
132\end{array}$ & & $n=63$ & & $\begin{array}{l}n= \\
233\end{array}$ & & $\begin{array}{l}n= \\
387\end{array}$ & & & & \\
\hline Protein E\% & $14(2)$ & 30 & $14(2)^{a}$ & 20 & ${ }_{h}^{16(3)^{a}}$ & 49 & $\ln _{h} 15(2)^{a}$ & 54 & $\begin{array}{l}16(3)^{a} \\
h r\end{array}$ & 61 & $\begin{array}{l}< \\
0.0001\end{array}$ & $<0.0001$ & $15-20$ \\
\hline Fat E\% & $36(5)$ & 84 & $37(5)^{a}$ & 70 & $34(6)^{\mathrm{h}}$ & 81 & $\begin{array}{l}34(6)^{a} \\
h\end{array}$ & 78 & $\begin{array}{l}37(6)^{j} \\
r\end{array}$ & 73 & 0.939 & 0.021 & $25-40$ \\
\hline $\begin{array}{l}\text { Carbohydrates } \\
\text { E\% }\end{array}$ & $47(5)$ & 64 & $45(5)^{\mathrm{a}}$ & 49 & $45(7)^{a}$ & 44 & $45(7)^{a}$ & 49 & $\begin{array}{l}40(7)^{a} \\
\text { h j r }\end{array}$ & 25 & $\begin{array}{l}< \\
0.0001\end{array}$ & $<0.0001$ & $45-60$ \\
\hline Alcohol E\% & $1(2)$ & 95 & $2(3)^{a}$ & 86 & $3(3)^{a}$ & 84 & $\begin{array}{l}4(4)^{a} \\
h j\end{array}$ & 76 & $\begin{array}{l}5(5)^{a} \\
h j\end{array}$ & 61 & $\begin{array}{l}< \\
0.0001\end{array}$ & $<0.0001$ & $<5$ \\
\hline Fibre E\% & $2(1)$ & & $2(1)$ & & $2(0.5)$ & & $2(1)$ & & $2(1)$ & & $\begin{array}{l}< \\
0.0001\end{array}$ & & No rec. \\
\hline
\end{tabular}

* Based on the Nordic nutrition recommendations (NNR) 2012

aSignificant difference compared with birth cohort1901-02

hSignificant difference compared with birth cohort 1911-12

significant difference compared with birth cohort 1922

rSignificant difference compared with birth cohort1930

yNNR recommended intake (RI) levels of macro- and micronutrients

and seeds increased from 0 to $76 \%$ among women, and from 0 to $72 \%$ among men, during the study period. Consumers of keyhole milk products increased between 1971 and 72 and 2000-02 but decreased between 200002 and 2014-16 among both sexes. However, consumers of non-keyhole milk products, cream, crème fraiche and cheese increased among both sexes during the study period, especially consumers of cream and crème fraiche. Consumers of pasta, rice, food grains and fibre-rich bread increased during the study period, and consumers of refined bread decreased. Consumers of desserts, sweets and candy, snacks and juice increased, among both sexes during the study period, and consumers of soda increased among men, but not among women.

\section{Alcohol intake}

There was a linear increase in mean gram intake of alcohol (Table 2) and alcoholic beverages (Table 5) among both sexes, during the study period (19812016). There was a linear increase in beer $(>2.8 \%$ alcohol $)(p<0.0001)$ and wine $(\mathrm{p}<0.0001)$ intake, a decrease in low alcohol beer $(<2.8 \%$ alcohol $)(p<$
0.0001) intake, but no linear change in mean liquor intake, among both sexes. Consumers of alcoholic beverages increased among both sexes, during the study period (Table 6). The proportion with an average alcohol intake above $10 \mathrm{~g} /$ day for women and $20 \mathrm{~g} /$ day for men, was $5 \%$ in women and $11 \%$ in men in 1981-83, $7 \%$ in women and $16 \%$ in men in $1992-93,15 \%$ in women and $21 \%$ in men in 2000 02 , and $33 \%$ in women and $32 \%$ in men in $2014-16$ (Fig. 2).

\section{Discussion}

Dietary patterns and nutrient intake changed considerably among 70-year-olds between 1971 and 2016, with overall healthier dietary patterns, and a higher nutrient density in later born birth cohorts. Especially, there was an increase in healthful foods, such as fruits (including berries), vegetables and pulses, fish and shellfish, nuts and seeds. In addition, there was an increase in protein intake and a decrease in the proportion of participants at risk of an inadequate vitamin and mineral intake in later born birth cohorts. However, the intake of alcohol 
Table 5 Time trends and comparisons between birth cohorts in food and beverage intake

\begin{tabular}{|c|c|c|c|c|c|c|}
\hline Birth cohort & $1901-02$ & $1911-12$ & 1922 & 1930 & 1944 & \\
\hline Examination years & $1971-72$ & $1981-83$ & 1992-93 & 2000-02 & 2014-16 & \\
\hline \multirow[t]{2}{*}{ Women } & $n=188$ & $n=130$ & $n=136$ & $n=321$ & $n=474$ & $\begin{array}{l}\text { Linear } \\
\text { trend }\end{array}$ \\
\hline & $\begin{array}{l}\text { Mean (SD) gram/ } \\
\text { day }\end{array}$ & $\begin{array}{l}\text { Mean (SD) gram/ } \\
\text { day }\end{array}$ & $\begin{array}{l}\text { Mean (SD) gram/ } \\
\text { day }\end{array}$ & $\begin{array}{l}\text { Mean (SD) gram/ } \\
\text { day }\end{array}$ & $\begin{array}{l}\text { Mean (SD) gram/ } \\
\text { day }\end{array}$ & $P$ value \\
\hline Fish and shellfish/seafood & $46(22)$ & $31(20)^{a}$ & $54(35)^{a \mathrm{~h}}$ & $54(36)^{a \mathrm{~h}}$ & $65(43)^{a h j ~ r ~}$ & $<0.0001$ \\
\hline Meat and processed meat & $66(39)$ & $78(42)^{a}$ & $84(45)^{a}$ & $81(41)^{a}$ & $69(40)^{\mathrm{h} \mathrm{j} \mathrm{r}}$ & 0.029 \\
\hline Poultry & $8(8)$ & $7(6)$ & $8(9)$ & $12(13)^{a \mathrm{~h} \mathrm{j}}$ & $22(25)^{a ~ h ~ j ~ r ~}$ & $<0.0001$ \\
\hline Eggs & $26(21)$ & $20(12)^{a}$ & $20(19)^{a}$ & $17(16)^{a}$ & $26(21)^{\mathrm{h} \mathrm{j} \mathrm{r}}$ & 0.074 \\
\hline Potatoes & $129(69)$ & $124(65)$ & $95(58)^{a} \mathrm{~h}$ & $97(51)^{a} \mathrm{~h}$ & $81(66)^{a ~ h ~ j ~ r ~}$ & $<0.0001$ \\
\hline Vegetables and pulses & $53(41)$ & $56(42)$ & $143(113)^{a \mathrm{~h}}$ & $145(94)^{\mathrm{a} h}$ & $205(123)^{a \mathrm{~h} \mathrm{j} \mathrm{r}}$ & $<0.0001$ \\
\hline Fruits and berries & $155(116)$ & $129(83)^{a}$ & $182(126)^{\mathrm{h}}$ & $205(134)^{a \mathrm{~h}}$ & $260(157)^{\text {a h j r }}$ & $<0.0001$ \\
\hline Keyhole milk products & $147(232)$ & $162(207)$ & $146(221)$ & $165(211)$ & $78(201)^{a \mathrm{~h} \mathrm{j} \mathrm{r}}$ & 0.007 \\
\hline Non-Keyhole milk products & $204(225)$ & $248(237)$ & $205(232)$ & $184(222)^{\mathrm{h}}$ & $189(182)^{\mathrm{h}}$ & 0.001 \\
\hline Cream and crème fraîche & $17(21)$ & $23(23)^{a}$ & $18(20)^{\mathrm{h}}$ & $23(23)^{a j}$ & $36(45)^{a ~ h ~ j ~ r ~}$ & $<0.0001$ \\
\hline Cheese & $28(19)$ & $32(21)$ & $43(36)^{a \mathrm{~h}}$ & $46(37)^{a \mathrm{~h}}$ & $49(45)^{a \mathrm{~h}}$ & $<0.0001$ \\
\hline Fast food & $0(0)$ & $0(2)$ & $0(3)^{a}$ & $2(6)^{a h ~ j}$ & $3(9)^{a ~ h ~ j ~ r ~}$ & $<0.0001$ \\
\hline Pasta, rice and food grain & $7(10)$ & $17(34)^{a}$ & $22(22)^{a}$ & $31(31)^{\mathrm{ah} \mathrm{j}}$ & $35\left((43)^{a ~ h ~ j ~}\right.$ & $<0.0001$ \\
\hline Bread refined & $61(50)$ & $48(52)^{a}$ & $37(46)^{a}$ & $35(41)^{a} \mathrm{~h}$ & $24(34)^{a ~ h ~ j ~ r ~}$ & $<0.0001$ \\
\hline Bread fibre-rich & $36(40)$ & $65(51)^{\mathrm{a}}$ & $54(38)^{a}$ & $65(45)^{a j}$ & $58(41)^{a} \mathrm{r}$ & $<0.0001$ \\
\hline Cereals & $92(98)$ & $94(87)$ & $63(74)^{a \mathrm{~h}}$ & $40(52)^{a \mathrm{~h} \mathrm{j}}$ & $42(58)^{a \mathrm{~h} \mathrm{j}}$ & $<0.0001$ \\
\hline Savoury bakery & $11(13)$ & $9(9)$ & $11(14)$ & $12(16)^{\mathrm{h}}$ & $12(14)^{\mathrm{h}}$ & 0.005 \\
\hline Sweet bakery & $54(44)$ & $53(45)$ & $35(29)^{a \mathrm{~h}}$ & $34(31)^{a} \mathrm{~h}$ & $21(24)^{a ~ h ~ j ~ r ~}$ & $<0.0001$ \\
\hline Desserts & $62(65)$ & $73(88)$ & $48(68)^{\mathrm{h}}$ & $53(62)^{\mathrm{h}}$ & $49(71)^{a \mathrm{~h}}$ & 0.003 \\
\hline Sweet condiments & $34(25)$ & $34(31)$ & $27(28)^{a}$ & $21(22)^{\mathrm{a} \mathrm{h} \mathrm{j}}$ & $14(18)^{a ~ h ~ j ~ r ~}$ & $<0.0001$ \\
\hline $\begin{array}{l}\text { Sweets, candy and } \\
\text { chocolate }\end{array}$ & $6(10)$ & $5(7)$ & $9(19)^{\mathrm{h}}$ & $11(12)^{a h}$ & $12(18)^{a ~ h}$ & $<0.0001$ \\
\hline Salads & $0(0)$ & $0(0)$ & $1(7)$ & $0(2)^{a h}$ & $4(19)^{a ~ h ~ j ~ r ~}$ & $<0.0001$ \\
\hline Soups & $33(22)$ & $42(28)^{a}$ & $40(48)$ & $50(53)^{a}$ & $29(40)^{\mathrm{h} \mathrm{j} \mathrm{r}}$ & $<0.0001$ \\
\hline Sauces and condiments & $0(0)$ & $0(0)$ & $5(12)^{a \mathrm{~h}}$ & $9(15)^{\text {a h j }}$ & $25(29)^{a ~ h ~ j ~ r ~}$ & $<0.0001$ \\
\hline Substitute products & $0(0)$ & $0(0)$ & $1(5)^{\mathrm{a} h}$ & $0(5)$ & $17(77)^{\text {a h j r }}$ & $<0.0001$ \\
\hline Margarine^ & $17(13)$ & $25(15)^{a}$ & $22(21)^{a}$ & $21(17)^{a \mathrm{~h}}$ & $12(12)$ & 0.045 \\
\hline Butter^ & $8(12)$ & $5(10)^{a}$ & $3(8)^{a}$ & $3(9)^{a ~ h}$ & $1(4)$ & $<0.0001$ \\
\hline Vegetable oil^ & $0(1)$ & $0(0)^{a}$ & $1(2)^{a h}$ & $3(5)^{\mathrm{a} \mathrm{h} \mathrm{j}}$ & $2(6)$ & $<0.0001$ \\
\hline Snacks & $0(0)$ & $0(0)$ & $0(1)^{a} \mathrm{~h}$ & $1(2)^{\mathrm{a} \mathrm{h} \mathrm{j}}$ & $2(8)^{a h ~ j ~ r ~}$ & $<0.0001$ \\
\hline Nuts and seeds & $0(0)$ & $0(0)$ & $2(6)^{a h}$ & $1(4)^{a h}$ & $12(17)^{\text {a h j r }}$ & $<0.0001$ \\
\hline Juice & $29(62)$ & $37(72)$ & $57(119)^{a}$ & $68(99)^{a} \mathrm{~h}$ & $49(85)^{a} \mathrm{r}$ & $<0.0001$ \\
\hline Coffee & $437(177)$ & $508(246)^{a}$ & $499(280)^{a}$ & $473(320)$ & $423(338)^{\mathrm{h} \mathrm{j} \mathrm{r}}$ & $<0.0001$ \\
\hline Tea & $146(59)$ & $169(82)^{a}$ & $122(312)$ & $136(200)^{h}$ & $195(280)^{a j ~ r ~}$ & $<0.0001$ \\
\hline Soda & $122(208)$ & $68(110)^{a}$ & $57(124)^{a}$ & $79(179)^{a}$ & $33(92)^{a ~ h ~ j ~ r ~}$ & $<0.0001$ \\
\hline Alcoholic beverages* & $46(75)$ & $49(81)$ & $63(99)$ & $90(109)^{h ~ j}$ & $107(127)^{\mathrm{h} \mathrm{j} \mathrm{r}}$ & $<0.0001$ \\
\hline Men & $n=182$ & $n=132$ & $n=63$ & $n=233$ & $n=387$ & \\
\hline Fish and shellfish/seafood & $58(35)$ & $43(25)^{a}$ & $69(39)^{a} \mathrm{~h}$ & $65(44)^{a} \mathrm{~h}$ & $77(57)^{\mathrm{a} \mathrm{h} \mathrm{r}}$ & $<0.0001$ \\
\hline Meat and processed meat & $80(30)$ & $96(47)^{\mathrm{a}}$ & $125(65)^{a} \mathrm{~h}$ & $110(49)^{a ~ h ~ j ~}$ & $97(51)^{\mathrm{a} \mathrm{j} \mathrm{r}}$ & 0.119 \\
\hline Poultry & $7(7)$ & $6(7)$ & $5(7)$ & $13(14)^{a ~ h ~ j ~}$ & $22(21)^{a ~ h ~ j ~ r ~}$ & $<0.0001$ \\
\hline
\end{tabular}


Table 5 Time trends and comparisons between birth cohorts in food and beverage intake (Continued)

\begin{tabular}{|c|c|c|c|c|c|c|}
\hline Eggs & $31(21)$ & $32(33)$ & $25(20)$ & $23(24)^{a} \mathrm{~h}$ & $30(24)^{r}$ & 0.462 \\
\hline Potatoes & $202(105)$ & $209(95)$ & $156(91)^{\mathrm{a} h}$ & $136(65)^{a} \mathrm{~h}$ & $125(91)^{\mathrm{a} \mathrm{h} \mathrm{j}}$ & $<0.0001$ \\
\hline Vegetables and pulses & $44(34)$ & $47(47)$ & $96(63)^{a} \mathrm{~h}$ & $129(101)^{a \mathrm{~h} \mathrm{j}}$ & $186(141)^{a ~ h ~ j ~ r ~}$ & $<0.0001$ \\
\hline Fruits and berries & $132(95)$ & $130(100)$ & $142(89)$ & $178(138)^{a} \mathrm{~h} \mathrm{j}$ & $228(173)^{\mathrm{a} \mathrm{h} \mathrm{j} \mathrm{r}}$ & $<0.0001$ \\
\hline Keyhole milk products & $118(235)$ & $171(283)$ & $158(255)$ & $162(253)$ & 59 (144) a h j r & 0.194 \\
\hline Non-Keyhole milk products & $267(273)$ & $313(278)$ & $219(239)^{\mathrm{h}}$ & $259(320)$ & $209(235)^{\mathrm{a} \mathrm{h} \mathrm{r}}$ & 0.253 \\
\hline Cream and crème fraîche & $15(21)$ & $19(22)$ & $15(21)$ & $21(20)^{a}$ & $29(31)^{a h j ~ r ~}$ & $<0.0001$ \\
\hline Cheese & $33(23)$ & $38(30)$ & $46(42)^{a}$ & $58(46)^{a \mathrm{~h}}$ & $43(31)^{\mathrm{a} r}$ & $<0.0001$ \\
\hline Fast food & $0(0)$ & $0(3)$ & $1(4)$ & $2(7)$ a h & $6(13)^{a h ~ j ~ r ~}$ & $<0.0001$ \\
\hline Pasta, rice and food grain & $8(12)$ & $14(17)^{\mathrm{a}}$ & $23(26)^{a} \mathrm{~h}$ & $35(37)^{\mathrm{a} \mathrm{h} \mathrm{j}}$ & $45(46)^{\mathrm{a} \mathrm{h} \mathrm{j} \mathrm{r}}$ & $<0.0001$ \\
\hline Bread refined & $86(64)$ & $92(68)$ & $55(56)^{a \mathrm{~h}}$ & $55(51)^{a \mathrm{~h}}$ & $34(44)^{a ~ h ~ j ~ r ~}$ & $<0.0001$ \\
\hline Bread fibre-rich & $43(54)$ & $57(65)^{a}$ & $76(54)^{a}$ & $78(56)^{a \mathrm{~h}}$ & $75(53)^{a \mathrm{~h}}$ & $<0.0001$ \\
\hline Cereals & $106(102)$ & $102(114)$ & $98(112)$ & $58(68)^{a ~ h ~ j ~}$ & $48(66)^{a h ~ j}$ & $<0.0001$ \\
\hline Savoury bakery & $17(15)$ & $15(14)$ & $11(13)^{a \mathrm{~h}}$ & $14(19)$ & $15(21)$ & 0.01 \\
\hline Sweet bakery & $64(60)$ & $56(46)$ & $43(41)^{a}$ & $45(35)^{a \mathrm{~h}}$ & $22(25)^{a h ~ j ~ r ~}$ & $<0.0001$ \\
\hline Desserts & $56(67)$ & $73(76)^{a}$ & $45(54)^{\mathrm{h}}$ & $57(73)^{\mathrm{h}}$ & $53(71)^{\mathrm{h}}$ & 0.798 \\
\hline Sweet condiments & $42(26)$ & $45(34)$ & $49(58)$ & $36(38)^{\mathrm{h}}$ & $17(20)^{a ~ h ~ j ~ r ~}$ & $<0.0001$ \\
\hline $\begin{array}{l}\text { Sweets, candy and } \\
\text { chocolate }\end{array}$ & $6(9)$ & $6(9)$ & $10(15)$ & $11(14)^{a \mathrm{~h}}$ & $12(18)^{a \mathrm{~h}}$ & $<0.0001$ \\
\hline Salads & $0(0)$ & $0(0)$ & $0(1)$ & $1(7)$ & $4(27)^{\mathrm{a} \mathrm{h} \mathrm{j} \mathrm{r}}$ & $<0.0001$ \\
\hline Soups & $41(34)$ & $54(43)^{a}$ & $66(139)$ & $51(60)^{a}$ & $35(53)^{\mathrm{h} \mathrm{r}}$ & $<0.0001$ \\
\hline Sauces and condiments & $0(0)$ & $0(0)$ & $4(14)^{a h}$ & $14(19)^{a ~ h ~ j ~}$ & $37(36)^{\mathrm{ah} \mathrm{j} \mathrm{r}}$ & $<0.0001$ \\
\hline Substitute products & $0(0)$ & $0(0)$ & $0(0)$ & $0(3)^{\mathrm{a}}$ & $9(49)^{a ~ h ~ j ~ r ~}$ & $<0.0001$ \\
\hline Margarine^$\wedge$ & $21(17)$ & $30(21)^{a}$ & $33(20)^{a}$ & $29(25)^{a}$ & $16(15)$ & 0.007 \\
\hline Butter^ & $11(15)$ & $11(20)$ & $2(7)^{a h}$ & $3(10)^{a h}$ & $2(7)$ & $<0.0001$ \\
\hline Vegetable oil^ & $1(1)$ & $0(0)$ & $1(2)^{a h}$ & $3(6)^{\mathrm{ah} \mathrm{j}}$ & $2(9)$ & $<0.0001$ \\
\hline Snacks & $0(0)$ & $0(0)$ & $0(0)$ & $1(3)^{a ~ h ~ j ~}$ & $2(6)^{a \mathrm{~h} \mathrm{j} \mathrm{r}}$ & $<0.0001$ \\
\hline Nuts and seeds & $0(0)$ & $0(1)$ & $0(1)^{a}$ & $2(10)^{a h ~ j}$ & $10(16)^{\mathrm{ah} \mathrm{j} \mathrm{r}}$ & $<0.0001$ \\
\hline Juice & $12(37)$ & $24(62)$ & $37(88)^{a}$ & $85(134)^{a \mathrm{~h} \mathrm{j}}$ & $72(112)^{a \mathrm{~h} \mathrm{j}}$ & $<0.0001$ \\
\hline Coffee & $486(229)$ & $572(254)^{a}$ & $520(363)$ & $499(348)^{\mathrm{h}}$ & $455(358)^{\mathrm{h}}$ & $<0.0001$ \\
\hline Tea & $162(76)$ & $191(85)^{a}$ & $129(194)^{\mathrm{h}}$ & $170(236)$ & $163(235)^{\mathrm{j}}$ & $<0.0001$ \\
\hline Soda & $120(199)$ & 99 (129) & $134(222)$ & $172(318)^{a \mathrm{~h}}$ & $57(138)^{a ~ h ~ j ~ r ~}$ & 0.041 \\
\hline Alcoholic beverages* & $183(193)$ & $164(207)$ & $160(168)$ & $231(228)^{\mathrm{h} \mathrm{j}}$ & $237(255)^{\mathrm{h} \mathrm{j}}$ & $<0.0001$ \\
\hline
\end{tabular}

* Linear trends in intake of alcoholic beverages are based on data from 1981 to 2016

$\wedge$ Linear trends in intake of margarine, butter and vegetable oil are based on data from 1971 to 2002

I Keyhole is the National Food Agency-labelling scheme, which guides healthy food choices. For milk and yogurt to meet the criteria for the Keyhole, fat content

has to be limited to a maximum of $0.7 \%$, and for flavoured products there is an additional limit for sugars: a maximum of $9 \%$

aSignificant difference compared with birth cohort1901-02

"Significant difference compared with birth cohort 1911-12

isignificant difference compared with birth cohort 1922

'Significant difference compared with birth cohort1930

increased successively across examinations since 1981, especially among women.

Some changes in food intake were expected since urbanisation, globalisation, technical development and lifestyle changes have influenced food consumption in Sweden over the last half-century [41]. A relative decrease in food prices, a broadened supply of food products, a higher import of different foods, an increased access to foods, as well as changes in socio-economic factors such as a higher educational level and better economy, could be some explanations for changes in dietary intake during the study period [41-43]. The degenerative processes of ageing and disease can affect dietary intake negatively, with a decrease in food intake and changes in food choices as a consequence [44]. During the study period there has been an increase in 
Table 6 Proportion consumers (\%) of each food group and changes in proportions during the study period

\begin{tabular}{|c|c|c|c|c|c|c|c|c|c|c|c|c|}
\hline & Women & & & & & & Men & & & & & \\
\hline Birth cohort & $\begin{array}{l}1901- \\
02\end{array}$ & $\begin{array}{l}1911- \\
12\end{array}$ & 1922 & 1930 & 1944 & & $\begin{array}{l}1901- \\
02\end{array}$ & $\begin{array}{l}1911- \\
12\end{array}$ & 1922 & 1930 & 1944 & \\
\hline \multirow[t]{2}{*}{ Examination years } & $\begin{array}{l}1971- \\
72\end{array}$ & $\begin{array}{l}1981- \\
83\end{array}$ & $\begin{array}{l}1992- \\
93\end{array}$ & $\begin{array}{l}2000- \\
02\end{array}$ & $\begin{array}{l}2014- \\
16\end{array}$ & & $\begin{array}{l}1971- \\
72\end{array}$ & $\begin{array}{l}1981- \\
83\end{array}$ & $\begin{array}{l}1992- \\
93\end{array}$ & $\begin{array}{l}2000- \\
02\end{array}$ & $\begin{array}{l}2014- \\
16\end{array}$ & \\
\hline & $n=188$ & $n=130$ & $n=136$ & $n=321$ & $n=474$ & $x^{2}$ & $\mathrm{n}=182$ & $\mathrm{n}=132$ & $n=63$ & $n=233$ & $n=387$ & $x^{2}$ \\
\hline Food groups & $\%$ & $\%$ & $\%$ & $\%$ & $\%$ & $P$ value & $\%$ & $\%$ & $\%$ & $\%$ & $\%$ & $P$ value \\
\hline Fish and shellfish/seafood & 98 & 99 & 98 & 98 & 99 & 0.472 & 98 & 99 & 98 & 98 & 100 & 0.063 \\
\hline Meat and processed meat & 100 & 100 & 97 & 98 & 98 & 0.186 & 100 & 98 & 100 & 99 & 99 & 0.243 \\
\hline Poultry & 67 & 79 & 66 & 75 & 94 & $\begin{array}{l}< \\
0.0001\end{array}$ & 67 & 67 & 52 & 74 & 92 & $\begin{array}{l}< \\
0.0001\end{array}$ \\
\hline Eggs & 81 & 89 & 86 & 89 & 94 & $\begin{array}{l}< \\
0.0001\end{array}$ & 90 & 94 & 100 & 91 & 96 & 0.006 \\
\hline Potatoes & 100 & 99 & 100 & 99 & 95 & $\begin{array}{l}< \\
0.0001\end{array}$ & 100 & 99 & 100 & 98 & 98 & 0.555 \\
\hline Vegetables and pulses & 98 & 99 & 98 & 100 & 100 & 0.021 & 94 & 98 & 98 & 100 & 100 & $\begin{array}{l}< \\
0.0001\end{array}$ \\
\hline Fruits and berries & 96 & 98 & 99 & 97 & 100 & 0.004 & 95 & 99 & 98 & 98 & 99 & 0.010 \\
\hline Keyhole milk products & 40 & 45 & 47 & 61 & 34 & $\begin{array}{l}< \\
0.0001\end{array}$ & 27 & 39 & 40 & 48 & 28 & $\begin{array}{l}< \\
0.0001\end{array}$ \\
\hline $\begin{array}{l}\text { Non-Keyhole milk } \\
\text { products }\end{array}$ & 60 & 71 & 75 & 75 & 82 & $\begin{array}{l}< \\
0.0001\end{array}$ & 65 & 74 & 67 & 72 & 83 & $\begin{array}{l}< \\
0.0001\end{array}$ \\
\hline Cream and crème fraîche & 57 & 75 & 83 & 89 & 90 & $\begin{array}{l}< \\
0.0001\end{array}$ & 52 & 65 & 68 & 82 & 84 & $\begin{array}{l}< \\
0.0001\end{array}$ \\
\hline Cheese & 87 & 95 & 96 & 96 & 98 & $\begin{array}{l}< \\
0.0001\end{array}$ & 87 & 90 & 95 & 97 & 99 & $\begin{array}{l}< \\
0.0001\end{array}$ \\
\hline Fast food & 0 & 1 & 3 & 10 & 29 & $\begin{array}{l}< \\
0.0001\end{array}$ & 0 & 1 & 3 & 12 & 33 & $\begin{array}{l}< \\
0.0001\end{array}$ \\
\hline Pasta, rice and food grain & 56 & 73 & 89 & 94 & 92 & $\begin{array}{l}< \\
0.0001\end{array}$ & 54 & 64 & 83 & 88 & 94 & $\begin{array}{l}< \\
0.0001\end{array}$ \\
\hline Bread refined & 80 & 68 & 63 & 73 & 62 & $\begin{array}{l}< \\
0.0001\end{array}$ & 81 & 84 & 73 & 83 & 66 & $\begin{array}{l}< \\
0.0001\end{array}$ \\
\hline Bread fibre-rich & 65 & 86 & 90 & 96 & 96 & $\begin{array}{l}< \\
0.0001\end{array}$ & 67 & 79 & 87 & 94 & 94 & $\begin{array}{l}< \\
0.0001\end{array}$ \\
\hline Cereals & 80 & 85 & 85 & 86 & 79 & 0.049 & 79 & 80 & 78 & 84 & 82 & 0.659 \\
\hline Savoury bakery & 62 & 75 & 68 & 69 & 83 & $\begin{array}{l}< \\
0.0001\end{array}$ & 76 & 77 & 70 & 66 & 77 & 0.015 \\
\hline Sweet bakery & 95 & 95 & 93 & 94 & 91 & 0.228 & 93 & 96 & 91 & 92 & 87 & 0.018 \\
\hline Desserts & 80 & 99 & 88 & 89 & 90 & $\begin{array}{l}< \\
0.0001\end{array}$ & 76 & 95 & 84 & 88 & 93 & $\begin{array}{l}< \\
0.0001\end{array}$ \\
\hline Sweet condiments & 94 & 93 & 93 & 94 & 93 & 0.912 & 94 & 96 & 92 & 94 & 95 & 0.813 \\
\hline $\begin{array}{l}\text { Sweets, candy and } \\
\text { chocolate }\end{array}$ & 64 & 54 & 79 & 85 & 90 & $\begin{array}{l}< \\
0.0001\end{array}$ & 61 & 59 & 68 & 71 & 82 & $\begin{array}{l}< \\
0.0001\end{array}$ \\
\hline Salads & 0 & 0 & 2 & 3 & 12 & $\begin{array}{l}< \\
0.0001\end{array}$ & 0 & 0 & 2 & 2 & 8 & $\begin{array}{l}< \\
0.0001\end{array}$ \\
\hline Soups & 92 & 93 & 83 & 83 & 75 & $\begin{array}{l}< \\
0.0001\end{array}$ & 88 & 92 & 89 & 83 & 76 & $\begin{array}{l}< \\
0.0001\end{array}$ \\
\hline Sauces and condiments & 0 & 0 & 43 & 70 & 91 & $\begin{array}{l}< \\
0.0001\end{array}$ & 0 & 0 & 30 & 79 & 94 & $\begin{array}{l}< \\
0.0001\end{array}$ \\
\hline Substitute products & 0 & 0 & 5 & 2 & 17 & $\begin{array}{l}< \\
0.0001\end{array}$ & 0 & 0 & 0 & 2 & 11 & $\begin{array}{l}< \\
0.0001\end{array}$ \\
\hline Margarine^ & 87 & 95 & 93 & 95 & 78 & 0.014 & 90 & 91 & 100 & 94 & 76 & 0.035 \\
\hline Butter^ & 40 & 32 & 27 & 34 & 12 & 0.109 & 46 & 39 & 22 & 32 & 16 & 0.002 \\
\hline
\end{tabular}


Table 6 Proportion consumers (\%) of each food group and changes in proportions during the study period (Continued)

\begin{tabular}{|c|c|c|c|c|c|c|c|c|c|c|c|c|}
\hline Vegetable oil^ & 4 & 0 & 21 & 58 & 23 & $\begin{array}{l}< \\
0.0001\end{array}$ & 2 & 1 & 14 & 52 & 21 & $\begin{array}{l}< \\
0.0001\end{array}$ \\
\hline Snacks & 0 & 0 & 6 & 17 & 41 & $\begin{array}{l}< \\
0.0001\end{array}$ & 0 & 0 & 0 & 13 & 36 & $\begin{array}{l}< \\
0.0001\end{array}$ \\
\hline Nuts and seeds & 0 & 0 & 15 & 22 & 76 & $\begin{array}{l}< \\
0.0001\end{array}$ & 0 & 1 & 13 & 20 & 72 & $\begin{array}{l}< \\
0.0001\end{array}$ \\
\hline Juice & 22 & 35 & 43 & 60 & 46 & $\begin{array}{l}< \\
0.0001\end{array}$ & 10 & 25 & 27 & 59 & 56 & $\begin{array}{l}< \\
0.0001\end{array}$ \\
\hline Coffee & 100 & 99 & 93 & 96 & 95 & 0.022 & 98 & 99 & 92 & 94 & 94 & 0.025 \\
\hline Tea & 100 & 99 & 34 & 63 & 72 & $\begin{array}{l}< \\
0.0001\end{array}$ & 98 & 99 & 38 & 60 & 71 & $\begin{array}{l}< \\
0.0001\end{array}$ \\
\hline Soda & 41 & 45 & 37 & 45 & 37 & 0.139 & 39 & 54 & 59 & 64 & 43 & $\begin{array}{l}< \\
0.0001\end{array}$ \\
\hline Alcoholic beverages* & 36 & 55 & 75 & 84 & 88 & $\begin{array}{l}< \\
0.0001\end{array}$ & 75 & 83 & 86 & 92 & 92 & $\begin{array}{l}< \\
0.0001\end{array}$ \\
\hline
\end{tabular}

*Comparisons of consumers of alcoholic beverages are based on data from 1981 to 2016

$\wedge$ Comparisons of consumers of margarine, butter and vegetable oils are based on data from 1971 to 2002

I Keyhole is the National Food Agency-labelling scheme, which guides healthy food choices. For milk and yogurt to meet the criteria for the Keyhole, fat content has to be limited to a maximum of $0.7 \%$, and for flavoured products there is an additional limit for sugars: a maximum of $9 \%$

average life expectancy from 77 to 84 years in women and from 72 to 81 years in men [45]. This increase could indicate that the birth cohort of 70 year olds examined in 2014-16 might have been healthier and less affected by the negative consequences of the ageing process and disease, and therefore more able to maintain a healthier dietary intake than 70-year olds examined in 1971. The increased media access and use of internet between 2000-02 and 2014-16 might have affected trends in dietary intake. In addition, there has been an increase in dietary cooking magazines and television shows during this period, as well as an increase in dietary articles in traditional newspapers. These sources give dietary advice, which are both in line with, and opposed to, official guidelines. Thus, many of the changes are probably due to period effects, rather than an effect of birth cohort and life-long dietary habits. Functional ability, including the ability to buy and prepare food, could also have an impact on dietary intake, and a previous H70 study, comparing 75-year olds born 30 years apart (1976-2006), showed that later born cohorts were less dependent in activities of daily living (ADL) and more engaged in leisure activities compared with earlier cohorts [46].

The increased intake of vegetables, fruit, meat, fish, cream, cheese, beer, wine, candy and snacks, and the decreased intake of milk, cereals, potatoes, sweet bakery and sugar was in line with the Swedish Board of Agriculture's report on food consumption in the Swedish population over the last 50 years [41], and with the National Food Agency's (NFA) population-based study "Riksmaten 2010-11" in Sweden [36]. However, the decrease in cereal intake might have been affected by changes in type of cereals consumed, from those containing more water, such as gruel, to dry foods such as muesli and bran flakes that weigh less.

The intake of certain healthful foods, such as fruits and vegetables, fish and seafood, nuts and seeds was highest in 2014-16, and consequently the proportion individuals at risk of insufficient vitamin-and mineral intakes, was lowest in those years. A study of dietary

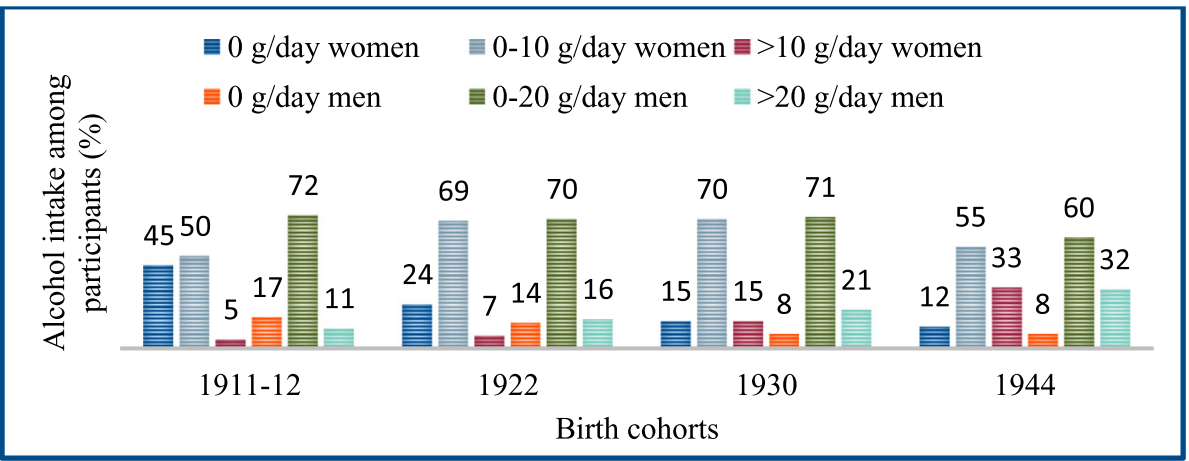

Fig. 2 Distribution of alcohol intake (gram/day) among participants 
intake among US adults, examined 1999-2012, showed similar trends among older adults ( $>65$ years), with increased intakes of whole grain products, nuts and seeds, fish and shellfish, cheese and protein and decreased intakes of milk, sugars and carbohydrates [47]. Dietary trends during the latter part of the study period, especially 2014-16, increasingly correspond to Mediterranean food patterns in the EPIC (EPIC-Elderly cohort) and SENECA studies $[48,49]$, where the southern European countries had a higher intake of fruits, vegetables, legumes, fish, wine and vegetable oils and a lower consumption of dairy products, sugar and cakes, than the northern European countries. Other studies have shown that high quality diets are related to higher education, non-smoking and greater physical activity [36, 48, 49]. This might have influenced our findings as greater proportions of participants in 2014-16 were non-smoking, highly educated and physically active, compared to earlier-born cohorts.

Mean energy intake increased during the study period, despite a shift towards a decreased energy intake among men between 2000-02 and 2014-16. The decrease in energy intake among men in 2014-16 might partially be due to underreporting of energy intake, since EI/BMR values between 2000-02 and 2014-16 also decreased. However, among women, the mean EI/BMR value was highest in 2014-16. Some misreporting of energy intake can be expected when examining dietary intake in a population, and underreporting of energy intake is common [31, 50-52]. Results from our study indicated that individuals with a higher BMI were more likely to underreport their energy intake, a result that is in line with other studies in older adults [53, 54]. However, mean EI/ BMR values were above the cut-off value (1.35) for potential underreporting of energy intake during the study period, and the sensitivity analyses, including only individuals with a EI/BMR value of $>1.35$, supported the overall time trends of differences in nutrient intake.

Mean energy intake, and E\% intake from macronutrients, were in line with the EPIC study, which examined older adults from nine European countries between 1992 and 2000 [48]. The Swedish longitudinal Västerbotten intervention programme (VIP) study, which examined dietary intake in a population from northern Sweden between 1996 and 2014, also exhibited similar patterns in $\mathrm{E} \%$ changes from macronutrient intake over a 10-year period (in four different age groups; 30, 40, 50 or 60 years at baseline) [55]. During the time period between 2000-02 and 2014-16, the low-carbohydrate and high fat diet was popular in Sweden $[41,56]$. This trend could potentially explain the decrease in E\% intake from carbohydrates and the increase in $\mathrm{E} \%$ intake from fat between 2000-02 and 2014-16, which negatively affected compliance to the $\mathrm{E} \%$ intake recommendations for carbohydrates and fat in 2014-16 [8]. The decrease in $\mathrm{E} \%$ intake from carbohydrates between 2000-02 and 2014-16 indicates changes in preferences towards fewer carbohydrate dense foods, e.g. less refined bread, cakes, buns and soda and more vegetables, pulses, fruits and berries. The increased $\mathrm{E} \%$ intake from fibre also indicates an increase in fibre-rich sources of carbohydrate intake, such as whole grain products and greens. The shift from key-hole milk products to non-keyhole milk products, together with the increase in cream and crème fraiche between 2000-02 and 2014-16, could also reflect this dietary trend [56].

The increase in alcohol intake was mainly due to an increase in wine and beer consumption, among both sexes. These results are in line with a previously published study examining risk consumption of alcohol, as reported from an interview by healthcare professionals, in the same population [57]. The results are also in line with "Riksmaten 2010-11" [36] and a report of selfreported alcohol intake in Sweden and might suggest a more continental and "quality of life" way of drinking $[58,59]$ in later born birth cohorts, which also partly follows other changes in dietary intake. A British study showed that alcohol intake among older adults decreased with deteriorating health, but increased among older adults with higher income and education [60]. The negative side effects of a higher alcohol intake could be an increased risk for disease, falls and fractures [61-63]. The National Board of Health and Welfare in Sweden recently reported that deaths associated with alcohol increased during the twenty-first century among older adults in Sweden, especially among women [64].

A higher protein intake could be beneficial in preventing and/or delaying age-related sarcopenia $[65,66]$. The PROMISS-study has examined protein intake in community-dwelling older adults, and results showed that a low protein $(\leq 1.0 \mathrm{~g} / \mathrm{kg} \mathrm{BW} /$ day $)$ intake is common among older adults $[67,68]$. In our study, mean intake of protein and protein-rich foods such as fish, poultry and meat increased during the study period, but despite this there was still more than $50 \%$ who had a protein intake below the recommended level of $1.2 \mathrm{~g} / \mathrm{kg}$ $\mathrm{BW} /$ day. These results indicate potential benefits of promoting healthy protein intake during the ageing process.

The higher nutrient density of vitamins and minerals in the later born birth cohorts were in line with Riksmaten 2010-11 [36]. The increase in participants having an intake of vitamin $\mathrm{C}$ and folate above requirements (AR) was most likely due to the increased fruit-, berries- and vegetable intake. However, there was a substantial proportion who did not reach the average requirement of $7.5 \mu \mathrm{g}$ of vitamin D/day. Even less reached the recommended intake level of $10 \mu \mathrm{g} /$ day, indicating that vitamin D supplements could be advisable in this age group 
(especially for those with a low intake of fish and fortified dairy products). However, the database used for the 2014-16 examination included values for vitamin D in fortified foods (e.g. dairy products) before values were increased in the late 2015 (our database was from January 2015) update of the national database [69]. Vitamin $\mathrm{D}$ intake from fortified foods might therefore be somewhat underestimated in the 2014-16 examination. In Sweden, flour was fortified with iron between 1944 and 1995. However, this has been taking into account when calculating iron intake in the 1971 to 1992-93 examinations.

A unique feature of this study is the fact that the dietary examination methodology has been comparable in all five birth cohorts, providing an opportunity to monitor dietary intake among older adults for a period of almost half a century. Other strengths are that the dietary examinations were performed by registered dietitians, and that the interviews were face-to face interviews, giving the participants an opportunity to describe their dietary intake in detail, in a way that would not be possible in a self-administered Food frequency questionnaire, (the most commonly used method in today's large-scale epidemiologic studies) [40]. Further, the interviews started with a $24 \mathrm{~h}$ recall of a regular day, which gave the interviewer an opportunity to cross check that intake of foods eaten regularly were not missed in the interview.

The study is not without limitations. For instance, dietary data from 1971-72, 1981-83, 1992-93, and 2000-02 were calculated in the Swedish NFA's nutrient database (PC-kost) after the 2000-02 examination [16]. When these calculations were done, there were several foods from the previous examinations (1971 to 1992-93) that were no longer listed in the 2000-02 database, so these were retrieved from earlier databases (based on the Swedish NFA's nutrient database of the time). The 2014-16 dietary examination was calculated in an updated version of the Swedish NFA's nutrient database 2015 [69]. However, we believe that the overall comparability between birth cohorts should not be affected, and that the benefits of using an updated database, including new foods and updates in nutrient content of foods, outweigh the disadvantages.

There is presently no dietary examination method that can measure exact intake in a larger population. There are individual differences in memory and recall, and in the ability to describe portion sizes and frequency. The latter is especially important in older populations. This uncertainty exists in most dietary examination methods [40], including ours. To capture new foods, the diet history method used in our study has been slightly modified between examinations. Questions about cooking fat were asked and registered somewhat differently in the 1944 birth cohort, as were alcohol intake in the birth cohort
1901-02, affecting comparability between birth cohorts. However, this should not affect overall comparability in dietary intake between cohorts to a significant degree. Further, participation rates varied between examinations, and the dietary examination was only performed in a smaller subsample in the first three examinations $[16,18]$, which might have affected the representability of the population.

With population ageing and growing, health promoting activities within public health are essential. This study provides an insight into dietary intake among older adults with a time perspective that is unique, and results from this study could be used as a basis for prevention strategies encouraging life style changes and disease preventive advice and guidelines for older adults. The increased intake of healthful foods, such as fish, nuts and seeds, fruits and vegetables, is encouraging, but compliance to dietary guidelines could still be improved, and the trend towards an increased alcohol intake among older adults should be paid attention to. The increase in important nutrients related to ageing, such as vitamin $\mathrm{D}$ and protein, is positive. However, more than $50 \%$ of the participants did not reach the recommended protein intake of $1.2 \mathrm{~g} / \mathrm{kg} \mathrm{BW} /$ day, and about $50 \%$ of the women and $30 \%$ of the men did not reach the average requirement level of $7.5 \mu \mathrm{g} /$ day intake of vitamin $\mathrm{D}$, and even less reached the recommended intake $(10 \mu \mathrm{g} /$ day $)$ [8], in the 2014-16 examination.

\section{Conclusion}

This study provides knowledge about dietary intake in relation to nutrient needs and dietary recommendations for older populations. It shows that dietary patterns have changed among 70-year-olds during the past five decades, with an increase in healthful foods and a higher nutrient density in later born birth cohorts. However, the intake of alcohol increased, especially among women. This knowledge contributes to insights in potential risk- and protective factors associated with diet and healthy ageing, and can be useful as a basis for dietary guidelines and used for prevention strategies involving older adults in populationbased and health care settings.

\section{Supplementary information}

Supplementary information accompanies this paper at https://doi.org/10. 1186/s12937-019-0493-8.

Additional file 1. Food groups.

Additional file 2. Check-list STROBE-Nut.

\section{Abbreviations}

AR: Average requirement; BMI: Body mass index; BMR: Basal metabolic rate; BW: Body weight; DH: Diet history; E\%: Percentages of energy; El: Energy intake; Kcal: Kilocalorie; MJ: Megajoul; NFA: National Food Agency; NNR 2012: Nordic Nutrition Recommendations 2012; PAL: Physical activity level; PPSW: The Population Study of Women in Gothenburg; Rl: Recommended intake 


\section{Acknowledgements}

Valter Sundh and Nazib Seidu for providing data for analyses and statistical support.

\section{Authors' contributions}

Principal investigator, resources and supervision: IS. Formal analyses: JS. Writing - original draft preparation: JS. Writing - review and editing: JS, ER, $L L, G E, A Z$, IS. All authors read and approved the final manuscript.

\section{Funding}

This research was supported by The Alcohol Research Council of the Swedish Alcohol Retailing Monopoly (no 2017-0051, 2016-0059), The Swedish Research Council (no 2017-01604, 2016-01590, 2015-02830, 20138717, 2012-5041), Swedish Research Council for Health, Working Life and Welfare (2016-07097, 2013-2496, AGECAP 2013-2300, 2013-1202, 20130475, 2013-8717), grants from the Swedish state under the agreement between the Swedish government and the county councils, the ALFagreement (ALF 716681, ALFGBG-720201), Forte for funding EpiLife Center (Forte 2006-1506) and Stiftelsen Handlanden Hjalmar Svenssons Forskningsfond.

\section{Availability of data and materials}

The datasets used and/or analysed during the current study are available from the corresponding author on reasonable request.

\section{Ethics approval and consent to participate}

Ethical approval was obtained from the Ethics Committee for Medical Research in Gothenburg, reference numbers 179-92, S22700 and 869-13. The tenets of the Declaration of Helsinki were followed and informed consent was obtained from all participants.

\section{Consent for publication}

Not applicable.

\section{Competing interests}

The authors declare that they have no competing interests.

\section{Author details}

Neuropsychiatric Epidemiology Unit, Department of Psychiatry and Neurochemistry, Institute of Neuroscience and Physiology, Sahlgrenska Academy, Centre for Ageing and Health (AgeCap) at the University of Gothenburg, Gothenburg, Sweden. ${ }^{2}$ Food and Meal Science, Kristianstad University, Kristianstad, Sweden. ${ }^{3}$ Department of Community Medicine and Public Health, at the University of Gothenburg, Gothenburg, Sweden. ${ }^{4}$ Department of Biomedicine and Public Health, University of Skövde, Skövde, Sweden.

Received: 2 July 2019 Accepted: 14 October 2019 Published online: 06 November 2019

\section{References}

1. United Nations. World Population Prospects 2019: Highlights 2019 [Available from: https://population.un.org/wpp/Publications/Files/WPP2019_1 OKeyFindings.pdf.

2. Eurostat; statistics explained. Population structure and ageing 2019 [Available from: https://ec.europa.eu/eurostat/statistics-explained/ pdfscache/1271.pdf.

3. The future population of Sweden 2018-2070. The future population of Sweden 2018-2070. Demographic reports 2018:1 2018 [Available from: https://www.scb.se/en/finding-statistics/statistics-by-subject-area/ population/population-projections/population-projections/pong/ publications/the-future-population-of-sweden-20182070/.

4. Prince MJ, Wu F, Guo Y, Gutierrez Robledo LM, O'Donnell M, Sullivan R, et al. The burden of disease in older people and implications for health policy and practice. Lancet. 2015;385(9967):549-62.

5. Tangney CC, Kwasny MJ, Li H, Wilson RS, Evans DA, Morris MC. Adherence to a Mediterranean-type dietary pattern and cognitive decline in a community population. Am J Clin Nutr. 2011;93(3):601-7.

6. Morris MC, Brockman J, Schneider JA, Wang Y, Bennett DA, Tangney CC, et al. Association of Seafood Consumption, brain mercury level, and APOE epsilon4 status with brain neuropathology in older adults. JAMA. 2016; 315(5):489-97.

7. Vergnaud AC, Romaguera D, Peeters PH, van Gils CH, Chan DS, Romieu I, et al. Adherence to the World Cancer Research Fund/American Institute for Cancer Research guidelines and risk of death in Europe: results from the European prospective investigation into nutrition and Cancer cohort study1,4. Am J Clin Nutr. 2013;97(5):1107-20.

8. Nordic Council of Ministers. Nordic Nutrition Recommendations 2012. Integrating nutrition and physical activity. 5th ed. . Copenhagen: Nordisk Ministerråd, 2014, 5. , p. 627.

9. Shlisky J, Bloom DE, Beaudreault AR, Tucker KL, Keller HH, Freund-Levi Y, et al. Nutritional considerations for healthy aging and reduction in agerelated chronic disease. Adv Nutr. 2017:8(1):17-26.

10. World Health Organization. World report on ageing and health 2015 [Available from: http:/www.who.int/ageing/publications/world-report-2015/en/.

11. Benziger $C P$, Roth $G A$, Moran AE. The global burden of disease study and the preventable burden of NCD. Glob Heart. 2016;11(4):393-7.

12. Bernstein $M$, Munoz N. Position of the academy of nutrition and dietetics: food and nutrition for older adults: promoting health and wellness. J Acad Nutr Diet. 2012;112(8):1255-77.

13. Bruins MJ, Van Dael $P$, Eggersdorfer $M$. The role of nutrients in reducing the risk for noncommunicable diseases during aging. Nutrients. 2019;11(1). https://doi.org/10.3390/nu11010085.

14. Robinson SM, Reginster JY, Rizzoli R, Shaw SC, Kanis JA, Bautmans I, et al. Does nutrition play a role in the prevention and management of sarcopenia? Clin Nutr. 2018;37(4):1121-32.

15. Rinder L, Roupe S, Steen B, Svanborg A. Seventy-year-old people in Gothenburg. A population study in an industrialized Swedish city. Acta Med Scand. 1975;198(5):397-407.

16. Eiben G, Andersson CS, Rothenberg E, Sundh V, Steen B, Lissner L. Secular trends in diet among elderly swedes -- cohort comparisons over three decades. Public Health Nutr. 2004;7(5):637-44.

17. Cabrera C, Rothenberg E, Eriksson BG, Wedel H, Eiben G, Steen B, et al. Socio-economic gradient in food selection and diet quality among 70-year olds. J Nutr Health Aging. 2007;11(6):466-73.

18. Rydberg Sterner T, Ahlner F, Blennow K, Dahlin-Ivanoff S, Falk H, Havstam Johansson L, et al. The Gothenburg H70 birth cohort study 2014-16: design, methods and study population. Eur J Epidemiol. 2019;34(2):191-209.

19. National Food Agency S. Nordic nutrition recommendations 2018 [Available from: https://www.livsmedelsverket.se/en/food-habits-health-andenvironment/dietary-guidelines/naringsrekommendationer.

20. World Health Organization. Diet, nutrition and the prevention of chronic diseases. Report of a joint WHO/FAO expert consultation (WHO Technical Report Series 916) 2003 [Available from: https://www.who.int/nutrition/ publications/obesity/WHO_TRS_916/en/.

21. European Food Safety Authority. Dietary Reference Values for nutrients Summary report 2017 [Available from: https://www.efsa.europa.eu/en/ supporting/pub/e15121.

22. Steen $B$, Djurfeldt $H$. The gerontological and geriatric population studies in Gothenburg. Sweden Z Gerontol. 1993;26(3):163-9.

23. Steen B. To become old. The Gerontological and geriatric population studies in Göteborg, Sweden, 1971-2002. Göteborg: Department of geriatric medicine, Sahlgrenska Academy at Göteborg University; 2004.

24. Bengtsson C, Ahlqwist M, Andersson K, Bjorkelund C, Lissner L, Soderstrom M. The prospective population study of women in Gothenburg, Sweden, 1968-69 to 1992-93. A 24-year follow-up study with special reference to participation, representativeness, and mortality. Scand J Prim Health Care. 1997;15(4):214-9.

25. Rothenberg E, Bosaeus I, Steen B. Food habits and nutrient intake in three 70-year-old free-living populations in Gothenburg, Sweden. A 22-year cohort study1996. 104-10 p.

26. Lissner L, Skoog I, Andersson K, Beckman N, Sundh V, Waern M, et al. Participation bias in longitudinal studies: Experience from the Population Study of Women in Gothenburg, Sweden2004. 242-7 p.

27. Eriksson BG, Mellstrom D, Svanborg A. Medical-social intervention in a 70year-old Swedish population. A general presentation of methodological experience. Comprehensive gerontology section C. Interdisciplinary topics. 1987;1:49-56.

28. Eiben G, Dey DK, Rothenberg E, Steen B, Bjorkelund C, Bengtsson C, et al. Obesity in 70-year-old swedes: secular changes over 30 years. Int J Obes. 2005;29(7):810-7. 
29. Sjogren A, Osterberg T, Steen B. Intake of energy, nutrients and food items in a tenyear cohort comparison and in a six-year longitudinal perspective: a population study of 70- and 76-year-old Swedish people. Age Ageing. 1994;23(2):108-12.

30. Rothenberg E, Bosaeus I, Lernfelt B, Landahl S, Steen B. Rothenberg E, Bosaeus I, Lernfelt B, Landahl S, Steen B. Energy intake and expenditure: validation of a diet history by heart rate monitoring, activity diary and doubly labeled water. Eur J Clin Nutr 52, 832-8381998. 832-838 p.

31. Rothenberg E, Bosaeus I, Steen B. Evaluation of energy intake estimated by a diet history in three free-living 70 year old populations in Gothenburg, Sweden1997. 60-6 p.

32. Kost och näringsdata. Dietist Net 2015 [Available from: http://www.kostdata. se/se/dietist-net.

33. Goldberg GR, Black AE, Jebb SA, Cole TJ, Murgatroyd PR, Coward WA, et al. Critical evaluation of energy intake data using fundamental principles of energy physiology: 1. Derivation of cut-off limits to identify under-recording. Eur J Clin Nutr. 1991;45(12):569-81.

34. Black $A E$, Cole TJ. Biased over- or under-reporting is characteristic of individuals whether over time or by different assessment methods. J Am Diet Assoc. 2001;101(1):70-80.

35. Bauer J, Biolo G, Cederholm T, Cesari M, Cruz-Jentoft AJ, Morley JE, et al. Evidence-based recommendations for optimal dietary protein intake in older people: a position paper from the PROT-AGE study group. J Am Med Dir Assoc. 2013;14(8):542-59.

36. National Food Agency S. Riksmaten 2010-11. Livsmedels- och näringsintag bland vuxna i Sverige - metodrapport (Intake of Foods and Nutrients Among Adults in Sweden - methodology report) 2010-11 [Available from: https://www.livsmedelsverket.se/globalassets/publikationsdatabas/ rapporter/2014/riksmaten-vuxna-2010-11-metodrapport\%2D\%2Drapport8\%2D\%2D-2014.pdf.

37. National Food Agency Sweden. The food database 2015 [Available from: https://www.livsmedelsverket.se/en/food-and-content/naringsamnen/ livsmedelsdatabasen.

38. Ax E, Warensjo Lemming E, Becker W, Andersson A, Lindroos AK, Cederholm T, et al. Dietary patterns in Swedish adults; results from a national dietary survey. Br J Nutr. 2016;115(1):95-104.

39. Lachat C, Hawwash D, Ocké MC, Berg C, Forsum E, Hörnell A, et al. Strengthening the Reporting of Observational Studies in EpidemiologyNutritional Epidemiology (STROBE-nut): An Extension of the STROBE Statement. PLoS Med. 2016;13(6):e1002036-e.

40. Hornell A, Berg C, Forsum E, Larsson C, Sonestedt E, Åkesson A, et al. An extension of the STROBE statement for observational studies in nutritional epidemiology (STROBE-nut): Explanation and elaboration2017.

41. Swedish Board of Agriculture. Livsmedelskonsumtionen i siffror - Hur har konsumtionen utvecklats de senaste femtio åren och varför 2015 [Available from: https://webbutiken.jordbruksverket.se/sv/artiklar/ra1515.html.

42. Atkins JL, Ramsay SE, Whincup PH, Morris RW, Lennon LT, Wannamethee SG. Diet quality in older age: the influence of childhood and adult socioeconomic circumstances. Br J Nutr. 2015;113(9):1441-52.

43. Conklin Al, Maguire ER, Monsivais P. Economic determinants of diet in older adults: systematic review. J Epidemiol Community Health. 2013;67(9):721-7.

44. Cederholm T, Jensen GL, Correia M, Gonzalez MC, Fukushima R, Higashiguchi T, et al. GLIM criteria for the diagnosis of malnutrition - a consensus report from the global clinical nutrition community. J Cachexia Sarcopenia Muscle. 2019;10(1):207-17.

45. Statistics S. The average life expectancy in Sweden (Medellivslängden i Sverige) 2019 [Available from: https://www.scb.se/hitta-statistik/sverige-isiffror/manniskorna-i-sverige/medellivslangd-i-sverige/.

46. Falk H, Johansson L, Ostling S, Thogersen Agerholm K, Staun M, Host Dorfinger $L$, et al. Functional disability and ability 75-year-olds: a comparison of two Swedish cohorts born 30 years apart. Age Ageing. 2014;43(5):636-41.

47. Rehm CD, Penalvo JL, Afshin A, Mozaffarian D. Dietary intake among US adults, 1999-2012. JAMA. 2016;315(23):2542-53.

48. Bamia C, Orfanos P, Ferrari P, Overvad K, Hundborg HH, Tjonneland A, et al. Dietary patterns among older Europeans: the EPIC-elderly study. Br J Nutr. 2005;94(1):100-13.

49. Haveman-Nies A, Tucker KL, de Groot LC, Wilson PW, van Staveren WA. Evaluation of dietary quality in relationship to nutritional and lifestyle factors in elderly people of the US Framingham heart study and the European SENECA study. Eur J Clin Nutr. 2001;55(10):870-80.

50. Mattisson I, Wirfält E, Aronsson C, Wallström P, Sonestedt E, Gullberg B, et al. Misreporting of energy: Prevalence, characteristics of misreporters and influence on observed risk estimates in the Malmö Diet and Cancer cohort2005. 832-42 p.

51. Nybacka S, Berteus Forslund H, Wirfalt E, Larsson I, Ericson U, Warensjo Lemming $E$, et al. Comparison of a web-based food record tool and a foodfrequency questionnaire and objective validation using the doubly labelled water technique in a Swedish middle-aged population. J Nutri Sci. 2016;5: e39.

52. Lopes TS, Luiz RR, Hoffman DJ, Ferriolli E, Pfrimer K, Moura AS, et al. Misreport of energy intake assessed with food records and 24-h recalls compared with total energy expenditure estimated with DLW. Eur J Clin Nutr. 2016;70(11):1259-64.

53. Meng X, Kerr DA, Zhu K, Devine A, Solah VA, Wright J, et al. Under-reporting of energy intake in elderly Australian women is associated with a higher body mass index. J Nutr Health Aging. 2013;17(2):112-8.

54. Bazelmans C, Matthys C, De Henauw S, Dramaix M, Kornitzer M, De Backer $\mathrm{G}$, et al. Predictors of misreporting in an elderly population: the 'Quality of life after 65' study. Public Health Nutr. 2007;10(2):185-91.

55. Winkvist A, Klingberg S, Nilsson LM, Wennberg M, Renstrom F, Hallmans G, et al. Longitudinal 10-year changes in dietary intake and associations with cardio-metabolic risk factors in the northern Sweden health and disease study. Nutr J. 2017;16(1):20.

56. Johansson I, Nilsson LM, Stegmayr B, Boman K, Hallmans G, Winkvist A. Associations among 25-year trends in diet, cholesterol and BMI from 140,000 observations in men and women in northern Sweden. Nutr J. 2012; $11: 40$

57. Ahlner F, Sigstrom R, Rydberg Sterner T, Mellqvist Fassberg M, Kern S, Ostling $S$, et al. Increased alcohol consumption among Swedish 70-yearolds 1976 to 2016: analysis of data from the Gothenburg H70 birth cohort studies, Sweden Alcohol. Clin Exp Res. 2018;42(12):2403-12.

58. Ortola R, Garcia-Esquinas E, Galan I, Rodriguez-Artalejo F. Patterns of alcohol consumption and health-related quality of life in older adults. Drug Alcohol Depend. 2016;159:166-73.

59. Guttormson U Gröndahl M. Självrapporterade alkoholvanor 2004-2017 (Selfreported alcohol consumption in Sweden 2004-2017), CAN 2018 [Available from: https://www.can.se/contentassets/14703e2c9a1340f49bfd35ef7da495 b1/befolkningens-sjalvrapporterade-alkoholvanor-2004-2017.pdf.

60. Holdsworth C, Frisher M, Mendonca M. C DEO, Pikhart H, Shelton N. Lifecourse transitions, gender and drinking in later life. Ageing Soc. 2017; 37(3):462-94.

61. Woods AJ, Porges EC, Bryant VE, Seider T, Gongvatana A, Kahler CW, et al. Current heavy alcohol consumption is associated with greater cognitive impairment in older adults. Alcohol Clin Exp Res. 2016;40(11):2435-44.

62. Scoccianti C, Cecchini M, Anderson AS, Berrino F, Boutron-Ruault MC, Espina $C$, et al. European code against Cancer 4th edition: alcohol drinking and cancer. Cancer Epidemiol. 2016;45:181-8.

63. Marley WD, Kelly G, Thompson NW. Alcohol-related fracture admissions: a retrospective observational study. Ulster Med J. 2015;84(2):94-7.

64. The National Board of Health and Welfare (Socialstyrelsen). Lägesrapport 2019 [Available from: https://www.socialstyrelsen.se/globalassets/sharepointdokument/artikelkatalog/ovrigt/2019-3-18.pdf.

65. Cruz-Jentoft AJ, Landi F, Schneider SM, Zúñiga C, Arai H, Boirie Y, et al. Prevalence of and interventions for sarcopenia in ageing adults: a systematic review. Report of the international sarcopenia initiative (EWGSOP and IWGS). Age Ageing. 2014:43(6):748-59.

66. Deutz NE, Bauer JM, Barazzoni R, Biolo G, Boirie Y, Bosy-Westphal A, et al. Protein intake and exercise for optimal muscle function with aging: recommendations from the ESPEN expert group. Clin Nutr. 2014;33(6):92936.

67. Hengeveld LM, Pelgröm ADA, Visser M, JMA B, Haveman-Nies A, HAH W. Comparison of protein intake per eating occasion, food sources of protein and general characteristics between community-dwelling older adults with a low and high protein intake. Clin Nutr ESPEN. 2018;29:165-74.

68. Wijnhoven HAH, Elstgeest LEM, de Vet HCW, Nicolaou M, Snijder MB, Visser M. Development and validation of a short food questionnaire to screen for low protein intake in community-dwelling older adults: the protein screener 55+ (Pro55+). PLoS One. 2018;13(5):e0196406.

69. National Food Agency S. The food database, updates. 2018.

\section{Publisher's Note}

Springer Nature remains neutral with regard to jurisdictional claims in published maps and institutional affiliations. 